$\Phi$

\title{
Phytochemical composition and antioxidant activity of extracts of some medicinal plants in Tunisia
}

\author{
Khaled Athmouni $^{1,2} *$, Taheni Belghith ${ }^{1,2}$, Abdelfattah El Fek ${ }^{2}$, Habib Ayadi ${ }^{1}$ \\ ${ }^{1}$ University of Sfax, Faculty of Sciences of Sfax, Department of life Sciences, research Unit UR 11 ES 72/Biodiversity and \\ Aquatic Ecosystems, Road Soukra Km 3,5, B.P. 1171, CP 3000 Sfax, Tunisia \\ ${ }^{2}$ Laboratory of Animal Ecophysiology, Faculty of Sciences of Sfax, University of Sfax, P.O. Box 95, Sfax 3000, Tunisia \\ *Corresponding author E-mail: Khaled_athmouni@hotmail.fr
}

\begin{abstract}
The aim of this study was to investigate the chemical composition of the best known plants biomarkers from the locality of Gafsa (Tunisia). Majority of investigated plants had high levels of phenolics and exhibited noteworthy antioxidant activity. The plants showing the highest antioxidant activities were $P$. angustifolia, T. garganica, G. alypum and L. multifida. P. angustifolia demonstrated by far the most potent antioxidant activity, as well as total phenolic and total flavonoids content. In flavonoid structure of the aerial parts of the related species, different amounts of rutin, myricetin, morin, quercetin and kaempferol together with ergosterol, stigma sterol and b-sitosterol as phytosterols, vitamin D, vitamin K, a-tocopherol and retinol as vitamins, and arabinose, fructose, glucose, sucrose and maltose as sugars were found. The mineral analysis was related to the existence of $\mathrm{Ca}, \mathrm{Na}, \mathrm{K}, \mathrm{Fe}, \mathrm{Mn}, \mathrm{Zn}$ and $\mathrm{Mg}$ with different amounts in all of the nine tested species.
\end{abstract}

Keywords: Medicinal Plant; Phytochemical Composition; HPLC Analysis; DPPH; ABTS.

\section{Introduction}

There is an increasing scientific interest in understanding effects of woody vegetation on agricultural lands for different aspects of human well-being, including the antioxidant activity (Žugić, et al., 2014) and nutrition (Agarwal, Durairajanayagam, \& du Plessis, 2014). Provisioning ecosystem services from vegetation were reported in 74 of the reviewed articles. Nutritional diversity is the most studied category, addressed in 56 studies in total for all species, followed by medicinal uses (40 studies) (Sinare \& Gordon, 2015). In addition, herbal medicines are known to have a strong reputation throughout history and within every culture to provide first-line and basic health services for patients with numerous disease conditions (Quimby, 2007). Plants have great importance due to their nutritive value and continue to be a major source of medicines as they have been found throughout human history (Kongkachuichai, Charoensiri, Yakoh, Kringkasemsee, \& Insung, 2015), 30 to $40 \%$ of today's conventional drugs used in the medicinal and curative properties of various plants are employed in herbal supplements botanicals, nutraceuticals and drug (Erdogan, Gonenc, Demirci, \& Kivçak, 2014; Polat, Cakilcioglu, Kaltalioğlu, Ulusan, \& Türkmen, 2015). In addition, medicinal plants are traditionally used in folk medicine as natural healing remedies with therapeutic effects such as prevention of cardiovascular diseases, inflammation disorders, or reducing the risk of cancer (Cavero, Akerreta, \& Calvo, 2013; Ibrahim \& Damasceno, 2012). Moreover, pharmacological industry utilizes medicinal plants due to the presence of active chemical substances as agents for drug synthesis. They are also valuable for food and cosmetic industry as additives, due to their preservative effects because of the presence of antioxidants and antimicrobial constituents (Cuoco, Mathe, \& Vieillescazes, 2014). Medicinal plants or parts of these plants (leaves, rhizomes, roots, seeds, flowers) can be utilized in different forms such as fresh crude form and preparations as teas, decoctions, powdered plant material, or extracted forms of medicinal agents (juices, water or alcohol extracts, tinctures, essential oils, resins, balsams). Moreover, medicinal plants are generally known and popular for a number of health benefits such as decreasing of blood pressure, prevention of cardiovascular diseases, or reducing the risk of cancer also due to their antioxidant activity. Therefore, the interest in natural (non toxic) antioxidants, especially of plant origin, has greatly increased in recent years (Jayasinghe, Gotoh, \& Wada, 2013). In recent years, studies on antioxidant activities of medicinal plants have increased remarkably due to increased interest in their potential of being used as arich and natural source of antioxidants (Boulanouar, Abdelaziz, Aazza, Gago, \& Miguel, 2013; Shan, Cai, Brooks, \& Corke, 2007). WHO estimates up to $80 \%$ of the population in developing countries, especially those who are poor, are dependent on traditional medicines from nature. Medicinal plants have been used to treat human diseases for thousands of years. People are becoming increasingly interested in medicinal plants because of their good therapeutic performance and low toxicity. Since traditional medicinal plants and food are believed to share a common origin in Chinese tradition, it is very difficult to distinguish traditional medicinal plants from food. Recently, interest has increased considerably in finding naturally occurring antioxidants for use in food or medicinal materials to replace synthetic antioxidants, which are being restricted due to their carcinogenicity (Velioglu, Mazza, Gao, \& Oomah, 1998). In fact, many medicinal plants have been used as flavors, pigments, and foods. The medicinal plants are thought to be a rich and natural source of functional food and pharmaceuticals. The health benefits of medicinal plants are thought to arise partly from potential effects of their antioxidants on the reactive oxygen species produced in the human body. In addition, several studies have indi- 
cated that medicinal plants possess more potent antioxidant activity than common dietary plants, and phenolic compounds were a major contributor to the antioxidant activity of these plants (Cavero, et al., 2013; Wong, Li, Cheng, \& Chen, 2006). The studies on the relation of phytochemical compounds and human health have been intensified. Phytochemical compounds (for example, vitamins, polyphenols, phytosterols and flavonoids) are known to protect human health against various diseases. Moreover, each of these compounds serves as antioxidant compound for the oxidative damage caused by free radicals (Garcia-Closas, Agudo, Gonzalez, \& Riboli, 1998; Li, Jiang, Zhang, Mu, \& Liu, 2008). The purpose of this study was to evaluate a variety of 9 medicinal plants belonging to the same location and have grown in the same conditions. This evaluation is related to the total phenolic content and antioxidant activity to find out new potential sources of natural antioxidants. Thus, the nutritional value of the species and its possible effect on human health has been studied.

\section{Materials and methods}

\subsection{Sample collection}

Nine plants have been evaluated in this study, namely Clematis flammula, Colocynthis vulgaris, Ecballium elaterium, Euphorbia bivonae, Globularia alypum, Lavandula multifida, Periploca angustifolia, Scorzonura undulata and Thapsia garganica.

The medicinal plants were collected in May 2014, from same place in Djebel Bouramli region of South west of Tunisia. The various data (local name, medicinal uses, used parts of plant, method of preparation and administration) were collected from local inhabitants having knowledge of the curative properties of these plants.

\subsection{Extractions of chemical compounds from the leaves}

The leaves of different plants $(20 \mathrm{~g})$ were powdered and extracted for $24 \mathrm{~h}$ with $250 \mathrm{ml}$ of methanol 96.6- at room temperature, followed by rapid paper filtration through Whatman $0.45 \mathrm{~mm}$ filter paper. The resulting solutions were evaporated under vacuum at $60{ }^{\circ} \mathrm{C}$ by a rotary evaporator (Büchi Rotavapor R-200, Büchi Heating Bath B-490). The residues were then dissolved in $6 \mathrm{ml}$ of methanol.

\subsection{Chemicals}

All chemicals were purchased from Sigma (represented by Tunisian Chemical Society).

\subsection{Total phenolic content}

Total phenolics content of these medicinal plants were measured by Folin-Ciocalteu's phenol reagent (J. W. Kim, et al., 2009, Singleton \& Rossi, 1965). First, $200 \mu 1$ of appropriately diluted sample or gallic acid standard were added to $2.6 \mathrm{ml}$ of distilled deionized water. Then, $200 \mu \mathrm{l}$ of Folin-Ciocalteu's phenol reagent was added at time zero and mixed. After $6 \mathrm{~min}, 2 \mathrm{ml}$ of 7\% (w/v) $\mathrm{Na}_{2} \mathrm{CO}_{3}$ solution was added and mixed. After incubation for 90 min at room temperature, absorbance was measured at $750 \mathrm{~nm}$ versus a prepared blank. The blank consisted of $200 \mu 150 \%$ (v/v) methanol instead of sample. Gallic acid in $50 \%(\mathrm{v} / \mathrm{v})$ methanol solution in concentrations of $0.1,0.3,0.5$, and $0.8 \mathrm{mg} \mathrm{ml}^{-1}$ was used as a standard and a calibration curve was drawn for each day of analysis. The content of total phenolic was expressed as $\mathrm{mg}$ gallic acid equivalent (GAE)/g of dry weight (DW). All determinations were analyzed in triplicate.

\subsection{Total flavonoids content}

Total flavonoid content was measured according to the method of (Zhishen, Mengcheng, \& Jianming, 1999). Sample extract was added with $0.3 \mathrm{ml}$ of $5 \%$ sodium nitrite and well mixed. After 5 min of incubation, $0.3 \mathrm{ml}$ of $10 \%$ aluminum chloride solution was added. Then, after $6 \mathrm{~min}, 2 \mathrm{ml}$ of $1 \mathrm{M}$ sodium hydroxide was added to the mixture and made up the volume to $10 \mathrm{ml}$ with water. The absorbance was measured at $510 \mathrm{~nm}$ with UV-visible spectrophotometer. Total flavonoids were measured from catechin $(0$ $0.3 \mathrm{mg}$ ) standard curve and expressed as $\mathrm{mg}$ catechin equivalents/g of dry weight. All samples were performed in triplicate.

\subsection{Determination of condensed tannins}

Condensed tannins content was determined by the vanillin method as described by (Broadhurst \& Jones, 1978). $3 \mathrm{ml}$ of vanillin (4\% in methanol) were added to $0.5 \mathrm{ml}$ of the different extracts. $1.5 \mathrm{ml}$ of highly concentrated $\mathrm{HCl}$ was then added. The mixture was then kept in the dark for $15 \mathrm{~min}$ at $20^{\circ} \mathrm{C}$. The absorbance was read at $500 \mathrm{~nm}$. A calibration curve was prepared with a solution of catechin. The results were obtained in $\mathrm{mg}$ of catechin equivalent per $\mathrm{g}$ of dry weight (mg CE/g DW). All samples were analyzed in triplicate.

\subsection{Total proteins and carbohydrates contents}

Proteins were quantified by (Lowry, Rosebrough, Farr, \& Randall, 1951) method, using a bovine serum albumin (BSA) calibration curve. This method is based on a reaction catalysed by copper contained in Folin reagent and the oxidation of peptide bonds with Folin-Ciocalteu reagent. Absorbance was measured at $750 \mathrm{~nm}$. The results were expressed as $\mathrm{mg}$ of protein per $\mathrm{ml}$ of extract. In addition, the total amount of simple sugars in the acid hydrolysates was determined by the phenol-sulfuric acid method (Dubois, Gilles, Hamilton, Rebers, \& Smith, 1956).

\subsection{Determination of flavonoid and resveratrol content}

Plant samples were homogenized in 1:5 $\left(\mathrm{g} \mathrm{ml}^{-1}\right)$ of methanol. The homogenate was filtered through filter paper. Its flavonoid and resveratrol content were determined by HPLC by putting $1 \mathrm{ml}$ of filtrate in the autosampler vials $(\mathrm{Zu}, \mathrm{Li}, \mathrm{Fu}, \& \mathrm{Zhao}, 2006)$. Catechin, naringin, rutin, resveratrol, myricetin, morin, naringenin, quercetin and kaempferol were quantified by DAD RPHPLC separation (High-performance liquid chromatography (HPLC) with diode array detector (DAD) is the most useful method for identification and quantification of antioxidant vitamins in biological fluids). The separation was performed at $280 \mathrm{~nm}$ for catechin and naringin, $254 \mathrm{~nm}$ for rutin, myricetin, morin and quercetin, 306 $\mathrm{nm}$ for resveratrol and $265 \mathrm{~nm}$ for kaempferol.

\subsection{Sugar analysis of diferentes plants}

Sugar compounds in the combined extracts were determined by using HPLC with a refractive index detector. Plant samples were homogenized in 1:1 $\left(\mathrm{g} \mathrm{ml}^{-1}\right)$ of distilled water. Supernatant phase was separated from the pellet. After total filtrate volume was determined, sugar compounds were analyzed by HPLC device and Shimpack HRC-NH2 (150 $94.6 \mathrm{~mm}, 5 \mathrm{~lm}$ ) column was used (Chromatography 2004).

\subsection{Mineral analysis}

The samples were dried at room temperature and were crushed in a mortar and pestle. Digestion of samples was performed using mixture of $\mathrm{HNO}_{3}: \mathrm{H}_{2} \mathrm{SO}_{4}: \mathrm{H}_{2} \mathrm{O}_{2}(10: 1: 1$, v/v/v for $1 \mathrm{~g}$ sample) and the samples were heated at $100{ }^{\circ} \mathrm{C}$ for about $15 \mathrm{~min}$. After cooling, $50 \mathrm{ml}$ deionized water was added and filtered. All sample solutions were clear. While amounts of $\mathrm{Fe}, \mathrm{Zn}, \mathrm{Mn}, \mathrm{Cu}, \mathrm{Co}, \mathrm{Ni}$ and $\mathrm{Mg}$ were determined by atomic absorption spectrometry (PerkinElmer, model: 370, USA), those of K, Ca and Na were determined by atomic emission spectrometer (AES) (Eppendorf Gerätebau Netheler \& Hinz GmbH) (Bragança, Melnikov, \& Zanoni, 2011). 


\subsection{Determination of phytosterol and vitamin content}

Vitamins and phytosterols were extracted from the lipid extracts by the method of Sanchez-Machado and Lopez- Cervantes et al with minor modifications (Lopez-Cervantes, Sanchez-Machado, \& Rios-Vazquez, 2006; Sánchez-Moreno, A. Larrauri, \& SauraCalixto, 1999). Plant sample $(1 \mathrm{~g})$ was homogenized with $5 \mathrm{ml}$ hexane and isopropyl alcohol $(3: 2, \mathrm{v} / \mathrm{v})$. The homogenate was filtered with filter paper. The filtrate was treated with $5 \mathrm{~mL}$ of $\mathrm{KOH}$ solution $(0.5 \mathrm{M}$ in methanol) and immediately vortexed. The tubes were placed in a water bath at $80{ }^{\circ} \mathrm{C}$ for $15 \mathrm{~min}$. After cooling in iced water, $1 \mathrm{ml}$ of distilled water and $5 \mathrm{ml}$ of hexane was added and the mixture was rapidly vortexed and then centrifuged for $5 \mathrm{~min}$ at $5,000 \mathrm{rpm}$. The supernatant was transferred to another test tube and was kept for drying under nitrogen. The detection was operated using two channels of a diode-array spectrophotometer $(326 \mathrm{~nm}$ for retinol and $202 \mathrm{~nm}$ for a-tocopherol and phytosterols) (Lopez-Cervantes, et al., 2006).

\subsection{Determination of the antioxidant activity}

\subsubsection{Free radical-scavenging activity on $\alpha$, $\alpha$-diphenyl-} bpicrylhydrazyl (DPPH)

The free radical scavenging capability of each extract solution on $\mathrm{DPPH}^{\circ}$ radicals was determined as described previously (Ozturk, Kolak, \& Meric, 2011). Briefly, $4 \mathrm{ml}$ of methanol solution of DPPH $(0.1 \mathrm{mM})$ was mixed with $1 \mathrm{ml}$ of each of extract (methanol, $\mathrm{n}$-hexane, water and ethyl acetate) solution at different concentrations $\left(0-0.4 \mathrm{mg} \mathrm{ml}^{-1}\right)$. The reaction mixture was incubated in a dark room for 30 minutes and the free radical scavenging ability was estimated by measuring the absorbance at $515 \mathrm{~nm}$ with the spectrophotometer. The reaction was carried out in capped glass test tubes that were tightly wrapped with aluminum foil. The DPPH radical stock solution was freshly prepared every day for the reaction, and precautionary measures were taken to reduce the loss of free radical activity during the experiment. The inhibition percentage of DPPH radicals was calculated as:

Inhibition $(\%)$ of DPPH radicals $=[(\mathrm{Ac}-\mathrm{As}) / \mathrm{Ac}] \times 100$

Where Ac is absorbance of the control reaction (all reagents except plant extract) and As is absorbance of the sample (plant extract).

\subsubsection{Free radical-scavenging ability by the use of ABTS•+ radical cation (ABTS assay)}

Antioxidant activities of diferentes plants were also analyzed by investigating their ability to scavenge the $\mathrm{ABTS}^{\cdot+}$ free radical using a modified methodology previously reported by (Ozgen, Reese, Tulio, Scheerens, \& Miller, 2006). When combined with an oxidant (2.45 mM potassium persulfate), ABTS $(7 \mathrm{mM}$ in $20 \mathrm{mM}$ sodium acetate buffer, $\mathrm{pH} 4.5$ ) reacts to create a stable, dark bluegreen radical solution following $12-16 \mathrm{~h}$ of incubation in the dark $\left(4{ }^{\circ} \mathrm{C}\right)$. The solution was then diluted to an absorbance of $0.7 \pm$ 0.01 at $734 \mathrm{~nm}$ to form the test reagent. Reaction mixtures containing $20 \mu \mathrm{l}$ of sample and $3 \mathrm{ml}$ of reagent were incubated in a water bath at $30{ }^{\circ} \mathrm{C}$ for $30 \mathrm{~min}$. As unpaired electrons are sequestered by antioxidants in the sample the test solution turns colorless and the absorbance at $734 \mathrm{~nm}$ is reduced. The final result was expressed as mmol of Trolox equivalents (TE) per g of dry weight (DW).

\subsection{Statistical analysis of data}

All experiments were repeated twice and carried out in a completely randomized block design; each treatment consisted of three replicates. Mean values of various treatments were subjected to analysis of variance (ANOVA) using IBM SPSS Statistics version 20 Significance level was determined (at $p<0.05$ ) and significant difference was separated using Duncan's Multiple Range Test (DMRT).

\section{Results and discussion}

\subsection{Phytochemical investigation}

Phenolic compounds are important constituents of plants, vegetables, and fruits because of their scavenging ability due to their hydroxyl groups. The phenolic compounds may contribute directly to the antioxidative action. In addition, it was reported that phenolic compounds were associated with antioxidant activity and play an important role in stabilizing lipid peroxidation (Yen \& Wu, 1999). The Folin-Ciocalteu method was used to measure the total phenolic contents of these plants. It relies on the transfer of electrons from phenolic compounds to the Folin-Ciocalteu reagent in alkaline media (Singleton \& Rossi, 1965). The results showed that the content of total phenols in extracts, expressed as gallic acid equivalents (GAE)/g dry weight (DW) of plan. Phenolic compounds can act as excellent radical scavengers and metal chelators that reduce oxidation because phenolic groups are nucleophiles and are able to inhibit lipid peroxidation, avoiding oxidation reaction by binding to free radicals generated through lipid peroxidation (Bravo, 1998). The results in Table.1 show the presence of phenolic compounds in different medicinal plants. The amount of total phenolics varied in different plants and ranged from $1.71 \pm$ 0.08 to $11.27 \pm 1.04 \mathrm{mg} \mathrm{GAE} / \mathrm{g}$ of dry weight. The highest total phenolic levels have been observed in Periploca angustifolia $(11.27 \pm 1.04 \mathrm{GAE} / \mathrm{g} \mathrm{DW})$, Thapsia garganica $(9.84 \pm 0.32$ GAE/g DW), Globularia alypum (8.04 $\pm 0.47 \mathrm{GAE} / \mathrm{g} \mathrm{DW})$ and Lavandula officinalis $(7.65 \pm 0.24 \mathrm{GAE} / \mathrm{g}$ DW). It has been noted that amount of total phenolic compounds in Asclepiadaceae varieties is higher then the other families. Among 9 families tested in this study, Asclepiadaceae (Periploca angustifolia), Apiaceae (Thapsia garganica), Globulariaceae (Globularia alypum), Asteraceae (Scorzonura undulata), Euphorbiaceae (Euphorbia bivonae), Cucurbitaceae (Colocynthis vulgaris and Ecballium elaterium) and Ranunculaceae (Clematis flammula), only Asclepiadaceae and Apiaceae families exhibited high levels of polyphenols (11.27 \pm 1.04 and $9.84 \pm 0.32 \mathrm{mg} \mathrm{GAE} / \mathrm{g} \mathrm{DW}$, respectively). The results obtained in the present study showed that the plants were relatively high but not very high in polyphenols. Total phenolic contents of the nine spices decreased in the following order: Periploca angustifolia $>$ Thapsia garganica $>$ Globularia alypum $>$ Lavandula officinalis $>$ Clematis flammula $>$ Euphorbia bivonae $>$ Colocynthis vulgaris $>$ Scorzonura undulata $>$ Ecballium elaterium. A significant difference $(* * * p<0.05)$ among phenolic content of each extract was observed at methanolic fraction of these families. Significant differences between the results were likely due to genotopic and environmental differences (namely, climate, location, temperature, fertility, diseases and pest exposure) within species, choice of tested parts, time of taking samples and determination methods (D.-O. Kim \& Lee, 2004; Shan, et al., 2007). Similarly, (Katalinic, Milos, Kulisic, \& Jukic, 2006) while studying phenolic content of 70 medicinal plants observed a significant variation. Pharmacists usually target the plant with high phenolic content to treat different diseases(Petti \& Scully, 2009). High amount of phenolic content indicates the ability of plant to treat inflammatory diseases and can be implicated in wound healing. In addition, phenolic compounds are plant metabolites characterized by the presence of several phenol groups. Some of them are very reactive in neutralizing free radicals by donating a hydrogen atom or an electron, chelating metal ions in aqueous solutions (Petti \& Scully, 2009). Flavonoids (polyphenolic plant compounds) possess a wide range of pharmacological properties. They do a lot for human health by scavenging free radicals (Robards, Prenzler, Tucker, Swatsitang, \& Glover, 1999). The amount of total flavonoids, measured by aluminum chloride method, varied widely in herb materials and ranged from $0.67 \pm 0.04$ to $3.92 \pm 0.06 \mathrm{mg}$ $\mathrm{CE} / \mathrm{g}$ dry weight (Table 1). Among the 9 medicinal plants, the seven plants with the highest total phenolic contents were Clematis flammula (3.92 $\pm 0.06 \mathrm{mg} \mathrm{CE} / \mathrm{g} \mathrm{DW})$, Thapsia garganica (3.21 $\pm 0.08 \mathrm{mg} \mathrm{CE} / \mathrm{g} \mathrm{DW})$, Euphorbia bivonae $(2.77 \pm 0.21 \mathrm{mg} \mathrm{CE} / \mathrm{g}$ 
DW), Lavandula officinalis (2.55 $\pm 0.12 \mathrm{mg} \mathrm{CE} / \mathrm{g} \mathrm{DW})$, Scorzonura undulata $(2.47 \pm 0.17 \mathrm{mg} \mathrm{CE} / \mathrm{g} \mathrm{DW})$, Periploca angustifolia $(2.46 \pm 0.32 \mathrm{mg} \mathrm{CE} / \mathrm{g} \mathrm{DW})$ and Ecballium elaterium $(2.35 \pm 0.14$ $\mathrm{mg} \mathrm{CE} / \mathrm{g} \mathrm{DW})$. Colocynthis vulgaris $(1.58 \pm 0.11 \mathrm{CE} / \mathrm{g} \mathrm{DW}) \mathrm{had}$ relatively low levels of phenolics, whereas Globularia alypum $(0.67 \pm 0.04 \mathrm{CE} / \mathrm{g} \mathrm{DW})$ in phenolics were quite low.

Many tannin-rich medicinal and food plants have been appreciated for their beneficial effects without being troubled by any obvious toxicity (K. Okuda, 1992). Research on the tannins in traditional medicinal plants, presented here, started (T. Okuda, 2005; Yoshida, Springel, White, \& Tormen, 2000). Table 1 shows the total phenolic content of these medicinal plants and the values were extremely different (up to 6 fold), ranging from $2.08 \pm 0.31$ to 12.72 $\pm 0.71 \mathrm{mg} \mathrm{CE} / \mathrm{g}$ dry weight of plant material. Among the nine medicinal plants, five plants with higher total phenolic contents were Clematis flammula $(12.72 \pm 0.71 \mathrm{mg} \mathrm{CE} / \mathrm{g}$ DW), Thapsia garganica (12.68 $\pm 0.43 \mathrm{mg} \mathrm{CE} / \mathrm{g} \mathrm{DW})$, Periploca angustifolia (12.58 $\pm 0.34 \mathrm{mg} \mathrm{CE} / \mathrm{g} \mathrm{DW})$, Euphorbia bivonae (11.42 $\pm 0.42 \mathrm{mg}$ $\mathrm{CE} / \mathrm{g} \mathrm{DW})$ and Globularia alypum $(11.08 \pm 0.51 \mathrm{mg}$ CE/g DW $)$. We also mentioned an increase of the phenolic metabolism in these xerophytes may be related to the hard climate conditions (hot temperatures, high solar exposure, dryness, short growing season) (Djeridane, et al., 2006). The lowest condensed tannins levels have been detected in Colocynthis vulgaris $(2.08 \pm 0.31 \mathrm{mg}$ $\mathrm{CE} / \mathrm{g} \mathrm{DW})$ and Ecballium elaterium (2.48 $\pm 0.05 \mathrm{mg} \mathrm{CE} / \mathrm{g} \mathrm{DW})$. It is clear from these results that, Ranunculaceae and Asclepiadaceae families are richer in condensed tannins than others families. In addition, the vegetable tannins (VTs) constitute one of the most widely distributed groups of all polyphenols in the plant (Kolodziej, Kayser, Latté, \& Ferreira, 1999), exhibiting a remarkably high structural diversity and wide range of physiological, biochemical, and pharmacological properties (antioxidant, antitumor, antiviral, antimicrobial, enzyme inhibition, radical scavenging, chemical defense, etc.) (Haslam, 1996).

Table 1: Total Phenol, Flavonoid Contents and Condensed Tannins for the Studied Plants

\begin{tabular}{|c|c|c|c|c|}
\hline \multicolumn{2}{|c|}{$\begin{array}{l}\text { Family and scientific } \\
\text { name }\end{array}$} & $\begin{array}{l}\text { Total phenol } \\
\text { (mg GAE/mg } \\
\text { DW) }\end{array}$ & $\begin{array}{l}\text { Flavonoids } \\
\text { (mg CE/g } \\
\text { DW) }\end{array}$ & $\begin{array}{l}\text { Condensed tan- } \\
\text { nins (mg CE/g } \\
\text { DW) }\end{array}$ \\
\hline $\begin{array}{l}\text { Clematis } \\
\text { flammula }\end{array}$ & $\begin{array}{l}\text { Ranun- } \\
\text { cula- } \\
\text { ceae }\end{array}$ & $7.37 \pm 0.23^{\mathrm{cd}}$ & $3.92 \pm 0.06^{\mathrm{d}}$ & $12.72 \pm 0.71^{\mathrm{j}}$ \\
\hline $\begin{array}{l}\text { Colocyn- } \\
\text { this vul- } \\
\text { garis }\end{array}$ & $\begin{array}{l}\text { Cucur- } \\
\text { bita- } \\
\text { ceae }\end{array}$ & $6.23 \pm 0.11^{\mathrm{b}}$ & $1.58 \pm 0.11^{\mathrm{b}}$ & $2.08 \pm 0.31^{\mathrm{a}}$ \\
\hline $\begin{array}{l}\text { Ecballium } \\
\text { elaterium }\end{array}$ & $\begin{array}{l}\text { Cucur- } \\
\text { bita- } \\
\text { ceae }\end{array}$ & $1.71 \pm 0.08^{\mathrm{a}}$ & $2.35 \pm 0.14^{\mathrm{c}}$ & $2.48 \pm 0.05^{\mathrm{b}}$ \\
\hline $\begin{array}{l}\text { Euphorbia } \\
\text { bivonae }\end{array}$ & $\begin{array}{l}\text { Eu- } \\
\text { phorbi- } \\
\text { aceae }\end{array}$ & $7.27 \pm 0.31^{\mathrm{bc}}$ & $2.77 \pm 0.21^{\mathrm{c}}$ & $11.42 \pm 0.42^{\mathrm{f}}$ \\
\hline $\begin{array}{l}\text { Globularia } \\
\text { alypum }\end{array}$ & $\begin{array}{l}\text { Globu- } \\
\text { laria- } \\
\text { ceae }\end{array}$ & $8.04 \pm 0.47^{d}$ & $0.67 \pm 0.04^{\mathrm{a}}$ & $11.08 \pm 0.51^{\mathrm{e}}$ \\
\hline $\begin{array}{l}\text { Lavandula } \\
\text { multifida }\end{array}$ & $\begin{array}{l}\text { Lami- } \\
\text { aceae }\end{array}$ & $7.65 \pm 0.24^{\mathrm{d}}$ & $2.55 \pm 0.12^{\mathrm{c}}$ & $7.68 \pm 0.27^{\mathrm{d}}$ \\
\hline $\begin{array}{l}\text { Periploca } \\
\text { angustifo- } \\
\text { lia }\end{array}$ & $\begin{array}{l}\text { Ascle- } \\
\text { piada- } \\
\text { ceae }\end{array}$ & $11.27 \pm 1.04^{\mathrm{f}}$ & $2.46 \pm 0.32^{\mathrm{c}}$ & $12.58 \pm 0.34^{\mathrm{j}}$ \\
\hline $\begin{array}{l}\text { Scorzonu- } \\
\text { ra undula- } \\
\text { ta }\end{array}$ & $\begin{array}{l}\text { Aster- } \\
\text { aceae }\end{array}$ & $5.48 \pm 0.19^{\mathrm{bc}}$ & $2.47 \pm 0.17^{\mathrm{c}}$ & $6.9 \pm 0.22^{\mathrm{c}}$ \\
\hline $\begin{array}{l}\text { Thapsia } \\
\text { garganica }\end{array}$ & $\begin{array}{l}\text { Apiace } \\
\text { ae }\end{array}$ & $9.84 \pm 0.32^{\mathrm{e}}$ & $3.21 \pm 0.08^{d}$ & $12.68 \pm 0.43^{j}$ \\
\hline
\end{tabular}

Data are presented as mean \pm SD of three individual determinations; GAE = gallic acid equivalents; $\mathrm{CE}=$ Catechin equivalents; $\mathrm{DW}=$ Dry weight; Values having different letters on a same column showed significant difference $(\mathrm{P}<0.05)$.

\subsection{Proteins and total carbohydrates content}

Quality control in the phytopharmaceutical industry includes the proof of identity of the raw material and the determination and quantification of specific compounds in single herbs, but also in resulting herbal drug preparations. Typically secondary metabolites are determined as leading compounds in plants; primary metabolites such as amino acids or carbohydrates play only a minor part. Nevertheless, the analysis of primary metabolites is also necessary, as these results are needed to explain the composition of a complex extract. Protein concentrates are widely used as ingredients in food industry because of their high nutritional quality, functional properties, high protein level and low content of antinutritional factors (Cordero-De-Los-Santos, Osuna-Castro, Borodanenko, \& Paredes-López, 2005). The most important criteria that determine the nutritional quality of plants, is the nutritional value of the plant (Dogan, Ugulu, \& Baslar, 2010). Crude protein contents of plants are influenced by a lot of environmental factors and the protein contents in different organs of plants in general are different. When a large part of the protein contents of plants (70 to $90 \%$ ) consists of amino acids, the remaining portion and the part called as non-proteins are formed from ammonium and nitrate salts. As can be seen, protein content is an important parameter in the determination of food values of plant nutrients. Protein contents of plant types used in the study was determined spectrophotometrically. The amount of total proteins, measured by Lowry method, varied widely in herb materials and ranged from $12.12 \pm$ 2.45 to $33.21 \pm 5.31 \mathrm{mg} \mathrm{ml}^{-1}$ of plant extract (Figure. 1). The highest protein concentration was observed in G. alypum (Globulariaceae). In contrast, the methanol extract of C. vulgaris showed lower protein content. G. alypum, E. bivonae, P. angustifolia, S. undulata, C. flammula, L. multifida and T. garganica had the highest protein contents $(33.21 \pm 5.31,32.67 \pm 1.65,30.11 \pm 2.08$, $29.84 \pm 1.84,29.15 \pm 3.07,28.96 \pm 3.71$ and $27.71 \pm 2.21 \mathrm{mg} \mathrm{ml}^{-}$ ${ }^{1}$ of plant extract, respectively), whereas $C$. vulgaris and E. elateri$u m$ showed the lowest protein contents $(12.12 \pm 2.45$ and $13.71 \pm$ $4.02 \mathrm{mg} \mathrm{ml}^{-1}$ plant extract). It has been reported that amount of total phenolic compounds in Globulariaceae varieties is higher than in other families. The differences were might be due to variation in genetic makeup, weather and geographic location of the plants and extraction procedure used or their phytochemicals (Akhtar, Ismail, Fraternale, \& Sestili, 2015).

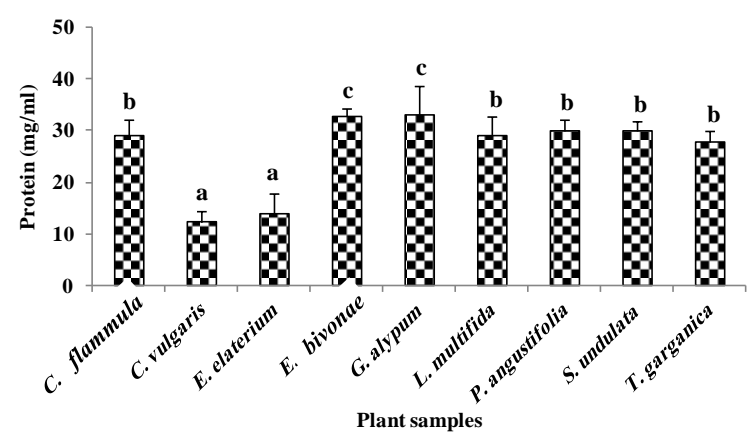

Fig. 1: Total Protein for the Studied Plants $\mathrm{Mg} / \mathrm{Ml}$ of Plant Extract. Values are Mean of Three Independent Determination $(\mathrm{N}=3) ; \pm$ Standard Deviation. Bars Having Different Letters are Significantly Different $(\mathrm{P}<0.05)$.

Carbohydrates are energy-rich molecules which provide energy for life processes and the building parts of the cellular structure of plants and animals (Harvey, 2009). They play an important role in the immune system, pathogenesis, blood clotting, fertilization, and protein folding and placement (Campa, Coslovi, Flamigni, \& Rossi, 2006). Their determination in plants is important for research, development and quality control analysis as they are one of the bioinformative macromolecules (Campa, et al., 2006). The total carbohydrates content of each family was quantified using the phenol-sulfuric acid method. We outlined that the amount of carbohydrates content in the aerial plants varies from $2.04 \pm 0.08$ to $4.87 \pm 0.12 \mathrm{mg} \mathrm{ml}^{-1}$ of plant extract. Figure 2 shows the total carbohydrates content of these medicinal plants and the values were slightly different (up to 2 fold). Among these plants, the top seven plants with the highest total sugar were $C$. flammula $(4.87 \pm$ $\left.0.12 \mathrm{mg} \mathrm{ml}^{-1}\right)$, L. multifida $\left(3.59 \pm 0.42 \mathrm{mg} \mathrm{ml}^{-1}\right), T$. garganica 
$\left(3.56 \pm 0.41 \mathrm{mg} \mathrm{ml}^{-1}\right), P$. angustifolia $\left(3.29 \pm 0.15 \mathrm{mg} \mathrm{ml}^{-1}\right), E$. bivonae $\left(3.09 \pm 0.31 \mathrm{mg} \mathrm{ml}^{-1}\right)$, G. alypum $\left(2.93 \pm 0.05 \mathrm{mg} \mathrm{ml}^{-1}\right)$ and $S$. undulata $\left(2.81 \pm 0.07 \mathrm{mg} \mathrm{ml}^{-1}\right)$. The lowest sugar content was observed in C. vulgaris $\left(2.04 \pm 0.08 \mathrm{mg} \mathrm{ml}^{-1}\right)$ and E. elaterium $\left(2.26 \pm 0.21 \mathrm{mg} \mathrm{ml}^{-1}\right)$.

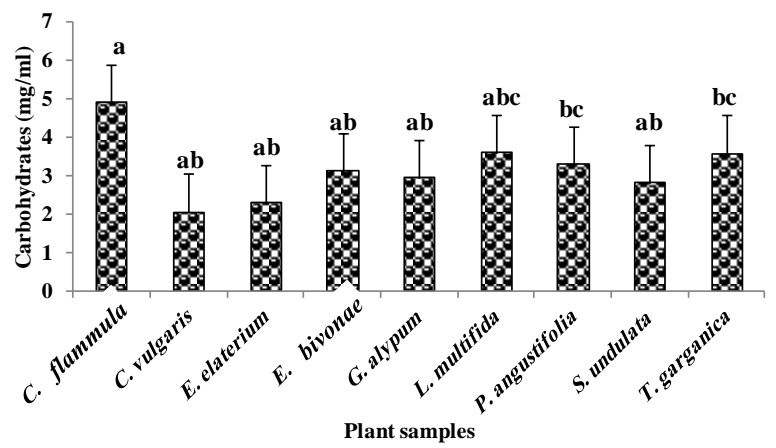

Fig. 2: Carbohydrates Content for the Studied Plants $\mathrm{Mg} / \mathrm{Ml}$ of Plant $\mathrm{Ex}$ tract, Values are Mean of Three Independent Determination $(\mathrm{N}=3)$; \pm Standard Deviation. Bars Having Different Letters are Significantly Different $(\mathrm{P}<0.05)$.

\subsection{Flavonoid and resveratrol content}

In recent years, plant flavonoids, which comprise a family of over 9000 compounds, have attracted a tremendous increase in research interest (Xiao, et al., 2011; Zheng, et al., 2011). This interest is mainly attributed to highly promising human health applications of specific flavonoids (Martin, Butelli, Petroni, \& Tonelli, 2011; Wedick, et al., 2012). The biological activities of flavonoid compounds have been investigated in relation to a multitude of human pathological conditions, including cancer, diabetes, obesity and Parkinson's disease (Qin, et al., 2012; Wang, Ramsey, \& Hamilton, 2011). According to the results of analysis Resveratrol and Kaempferol were found in each of the family species. Major flavonoid compounds were isolated and identified from many Tunisia medicinal plants (C. flammula, $C$. vulgaris, E. elaterium, E. bivonae, G. alypum, L. multifida, $P$. angustifolia, $S$. undulata and $T$. garganica) using DAD RP-HPLC under the chromatographic conditions employed for the first time. For instance, several flavonoids and flavone glycoside were isolated and identified in the leaves of plant samples. Major types and representative components of natural flavonoids (Rutin, Myricetin, Morin, Quercetin, Kaempferol and Naringenin) identified in the 9 selected medicinal plants are summarized in Table 2. Rutin was found in majority of the methanolic fraction of $P$. angustifolia $(15.65 \pm$ $\left.0.31 \mu \mathrm{g} \mathrm{g}^{-1}\right), C$. vulgaris $\left(13.57 \pm 0.23 \mu \mathrm{g} \mathrm{g}^{-1}\right), T$. garganica $(13.42$ $\left.\pm 0.23 \mu \mathrm{g} \mathrm{g}^{-1}\right)$, C. flammula $\left(12.45 \pm 0.21 \mu \mathrm{g} \mathrm{g}^{-1}\right)$, G. alypum $\left(11.86 \pm 0.18 \mu \mathrm{g} \mathrm{g}^{-1}\right)$, E. bivonae $\left(10.08 \pm 0.06 \mu \mathrm{g} \mathrm{g}^{-1}\right)$, E. elaterium $\left(9.23 \pm 0.07 \mu \mathrm{g} \mathrm{g}^{-1}\right)$ and L. multifida $\left(8.72 \pm 0.24 \mu \mathrm{g} \mathrm{g}^{-1}\right)$. Therefore, it can be deduced that rutin is the major flavonoid compound contributing to the antioxidant activity of the most of the plants. On the other side, rutin was not found in Scorzonera species used in the study. The quercetin contents of plant extracts varied from $1.56 \pm 0.06$ to $4.23 \pm 0.04 \mu \mathrm{g} \mathrm{g}^{-1}$ of plant samples. $C$. flammula had the highest quercetin content $\left(4.23 \pm 0.04 \mu \mathrm{g} \mathrm{g}^{-1}\right)$, followed by $T$. garganica $\left(4.05 \pm 0.14 \mu \mathrm{g} \mathrm{g}^{-1}\right)$ and G. alypum (3.46 $\left.\pm 0.11 \mu \mathrm{g} \mathrm{g}^{-1}\right)$. The lowest quercetin levels have been detected in $P$. angustifolia $\left(1.56 \pm 0.03 \mu \mathrm{g} \mathrm{g}^{-1}\right)$ and E. bivonae $(1.76 \pm 0.06 \mu \mathrm{g}$ $\left.\mathrm{g}^{-1}\right)$. The flavonoids rutin and quercetin are polyphenolics compounds found in vegetables, fruits, herbs, leaves, seed, red wine, tea, coffee, beer, and several medicinal plants. Rutin is a bioflavonoid and antioxidant (De Azevedo, 2013). It is water-soluble and converted to quercetin once it enters the blood stream (Morand, Manach, Crespy, \& Remesy, 2000). Several studies have found that these flavonoids have anti-inflammatory (Ferrandiz \& Alcaraz, 1991), analgesic (Emim, et al., 2000), and antioxidant effects. In addition, food derived flavonoids, especially; flavonols (kaempeferol, quercetin and myricetin) are widely occurring flavonoids and are reported to exhibit multiple biological functions such as anti-allergenic, anti-artherogenic, anti-inflammatory, antimicrobial, anti-thrombotic, anti-oxidant, cardioprotective and vasodilatory effects (Manach, Williamson, Morand, Scalbert, \& Remesy, 2005) Moreover, results showed that $E$. bivonae and $P$. angustifolia leaves contained highest amount of total flavonols (myricetin and Morin, respectively). The range of myricetin content was $1.72 \pm$ $0.09-5.46 \pm 0.12 \mu \mathrm{g} \mathrm{g}^{-1}$ of dry weight. The ranking of plant samples on the basis of myricetin contents in decreasing order is $E$. bivonae $\left(5.46 \pm 0.12 \mu \mathrm{g} \mathrm{g}^{-1}\right)>C$. vulgaris $\left(4.12 \pm 0.04 \mu \mathrm{g} \mathrm{g}^{-1}\right)>S$. undulata $\left(4.06 \pm 0.1 \mu \mathrm{g} \mathrm{g}^{-1}\right)>T$. garganica $\left(3.86 \pm 0.05 \mu \mathrm{g} \mathrm{g}^{-1}\right)>$ $P$. angustifolia $\left(3.52 \pm 0.02 \mu \mathrm{g} \mathrm{g}^{-1}\right)>$ E. elaterium $(3.14 \pm 0.03 \mu \mathrm{g}$ $\left.\mathrm{g}^{-1}\right)>$ C. flammula $\left(2.42 \pm 0.07 \mu \mathrm{g} \mathrm{g}^{-1}\right)>$ G. alypum $(2.08 \pm 0.05$ $\left.\mu \mathrm{g} \mathrm{g}^{-1}\right)>$ L. multifida $(1.72 \pm 0.09 \mu \mathrm{g} / \mathrm{g})$. Less information is available regarding the contents of myricetin in plant used in the present work. Data for flavonol contents of different plants, showed the presence of morin in all investigated families; however, its level varied widely ranging from highest in $L$. multifida $\left(0.96 \pm 0.001 \mu \mathrm{g} \mathrm{g}^{-1}\right)$ to lowest in P. angustifolia $(0.32 \pm 0.01 \mu \mathrm{g}$ $\left.\mathrm{g}^{-1}\right)$. On the other side, morin was not detected in G. alypum and $E$. bivonae. Morin has been reported for its potent antioxidant (Hou, 2003) and other pharmacological properties including antimutagenesis (Yang, et al., 2008), anti-inflammation (Yang, et al., 2008), cardio protection (Kok, et al., 2000). The naringenin levels in the investigated vegetables ranged from $0.36 \pm 0.03$ to $0.86 \pm$ $0.04 \mu \mathrm{g} \mathrm{g}^{-1}$ of dry weights. The highest level was detected in $E$. bivonae $\left(0.86 \pm 0.04 \mu \mathrm{g} \mathrm{g}^{-1}\right)$, followed by $S$. undulata $(0.85 \pm 0.01$ $\left.\mu \mathrm{g} \mathrm{g}^{-1}\right)$, and C. flammula $\left(0.78 \pm 0.01 \mu \mathrm{g} \mathrm{g}^{-1}\right)$. Lowest naringenin level was observed for E. elaterium $\left(0.36 \pm 0.03 \mu \mathrm{g} \mathrm{g}^{-1}\right)$, followed by $T$. garganica $\left(0.37 \pm 0.02 \mu \mathrm{g} \mathrm{g}^{-1}\right)$, L. multifida $(0.48 \pm 0.02 \mu \mathrm{g}$ $\left.\mathrm{g}^{-1}\right)$, and $C$. vulgaris $\left(0.54 \pm 0.02 \mu \mathrm{g} \mathrm{g}^{-1}\right)$. In addition, naringenin is a flavanone, a type of flavonoid, that is considered to have a bioactive effect on human health as antioxidant, free radical scavenger, anti-inflammatory, carbohydrate metabolism promoter, and immune system modulator.

Table 2: Flavonoids and Resveratrol Content in Plant Species $(\mu \mathrm{g} / \mathrm{G})$

\begin{tabular}{|c|c|c|c|c|c|c|c|c|c|}
\hline $\begin{array}{l}\text { Flavonoids \& } \\
\text { resveratrol }\end{array}$ & C. flammula & C. vulgaris & E. elaterium & E. bivonae & G. alypum & L. multifida & P. angustifolia & S. undulata & T. garganica \\
\hline Rutin & $12.45 \pm 0.21^{\mathrm{c}}$ & $13.57 \pm 0.23^{c}$ & $9.23 \pm 0.07^{\mathrm{a}}$ & $10.08 \pm 0.06^{\mathrm{ab}}$ & $11.86 \pm 0.18^{\mathrm{bc}}$ & $8.72 \pm 0.24^{\mathrm{a}}$ & $15.65 \pm 0.31^{\mathrm{d}}$ & - & $13.42 \pm 0.23^{\mathrm{c}}$ \\
\hline Myricetin & $2.42 \pm 0.07^{\mathrm{ab}}$ & $4.12 \pm 0.04^{b c}$ & $3.14 \pm 0.03^{\mathrm{ab}}$ & $5.46 \pm 0.12^{\mathrm{bc}}$ & $2.08 \pm 0.05^{\mathrm{ab}}$ & $1.72 \pm 0.09^{\mathrm{a}}$ & $3.52 \pm 0.02^{\mathrm{ab}}$ & $4.06 \pm 0.1^{\mathrm{bc}}$ & $3.86 \pm 0.05^{\mathrm{ab}}$ \\
\hline Morin & $0.87 \pm 0.03^{\mathrm{d}}$ & $0.64 \pm 0.01^{b c}$ & $0.47 \pm 0.06^{\mathrm{ab}}$ & - & - & $0.32 \pm 0.01^{\mathrm{a}}$ & $0.96 \pm 0.001^{\mathrm{d}}$ & $0.72 \pm 0.03^{\mathrm{c}}$ & $0.54 \pm 0.03^{\mathrm{ab}}$ \\
\hline Quercetin & $4.23 \pm 0.04^{c}$ & $3.07 \pm 0.11^{\mathrm{cd}}$ & $2.45 \pm 0.05^{\mathrm{bc}}$ & $1.76 \pm 0.06^{\mathrm{a}}$ & $3.46 \pm 0.11^{\mathrm{a}}$ & $2.76 \pm 0.07^{\mathrm{ab}}$ & $1.56 \pm 0.06^{\mathrm{c}}$ & $2.42 \pm 0.21^{\mathrm{cd}}$ & $4.05 \pm 0.14^{b c}$ \\
\hline Kaempferol & - & - & - & - & - & - & - & - & - \\
\hline Naringenin & $0.78 \pm 0.01^{\mathrm{bc}}$ & $0.54 \pm 0.02^{c}$ & $0.36 \pm 0.03^{\mathrm{a}}$ & $0.86 \pm 0.04^{\mathrm{c}}$ & $0.64 \pm 0.03^{\mathrm{abc}}$ & $0.48 \pm 0.02^{\mathrm{ab}}$ & $0.57 \pm 0.04^{\mathrm{abc}}$ & $0.85 \pm 0.01^{\mathrm{c}}$ & $0.37 \pm 0.02^{\mathrm{a}}$ \\
\hline Resveratrol & - & - & 一 & - & - & - & - & - & - \\
\hline
\end{tabular}

Each value is the mean \pm standard deviation of five determinations. Values having different letters on a same column showed significant difference $(* \mathrm{P}<$ $0.05)$.

\subsection{Sugar contents of plant samples}

The plants investigated in our study had a total sugar contents varying from $859.91 \pm 8.17$ to $2153.74 \pm 14.02 \mu \mathrm{g} \mathrm{g}^{-1}$ of the extract. We found that the glucose was the major sugar in plant sam- ples. The presence of glucose (monosaccharides) was noticed in 9 plants, with values ranged from $374.26 \pm 2.14 \mu \mathrm{g} \mathrm{g}^{-1}$ in L. multifida to $872.37 \pm 1.07 \mu \mathrm{g} \mathrm{g}^{-1}$ in $C$. vulgaris, followed by $S$. undulata $\left(832.43 \pm 4.06 \mu \mathrm{g} \mathrm{g}^{-1}\right), P$. angustifolia $\left(741.68 \pm 0.54 \mu \mathrm{g} \mathrm{g}^{-1}\right), E$. bivonae $\left(704.23 \pm 1.52 \mu \mathrm{g} \mathrm{g}^{-1}\right), T$. garganica $(674.12 \pm 2.45 \mu \mathrm{g} \mathrm{g}$ 
$\left.{ }^{1}\right)$, C. flammula $\left(654.41 \pm 2.34 \mu \mathrm{g} \mathrm{g}^{-1}\right)$, E. elaterium $(546.05 \pm$ $\left.0.25 \mu \mathrm{g} \mathrm{g}^{-1}\right)$, G. alypum $\left(451.54 \pm 3.04 \mu \mathrm{g} \mathrm{g}^{-1}\right)$ and L. multifida $\left(374.26 \pm 2.14 \mu \mathrm{g} \mathrm{g}^{-1}\right)$. Fructose (monosaccharide) was the second most abundant sugar detected in the samples analyzed in the present work. Highest level was detected in C. vulgaris $(756.23 \pm$ $\left.0.86 \mu \mathrm{g} \mathrm{g}^{-1}\right)$, followed by S. undulata $(725.46 \pm 2.81 \mu \mathrm{g} / \mathrm{g})$. Saccharose was also detected in all samples. Highest level of saccharose was detected in $S$. undulata leaves $\left(542.64 \pm 3.72 \mu \mathrm{g} \mathrm{g}^{-1}\right)$, followed by $T$. garganica leaves $\left(536.87 \pm 4.02 \mu \mathrm{g} \mathrm{g}^{-1}\right), P$. angustifolia $\left(453.75 \pm 2.57 \mu \mathrm{g} \mathrm{g}^{-1}\right)$, E. bivonae $(421.36 \pm 1.58 \mu \mathrm{g} \mathrm{g}$ ${ }^{1}$ ), and $C$. flammula $\left(356.87 \pm 1.75 \mu \mathrm{g} \mathrm{g}^{-1}\right)$. The lowest saccharose levels have been detected in E. elaterium, L. multifida, C. vulgaris and G. alypum. Arabinose and maltose were found in minority of extracts except in the methanolic extracts of different families. The difference in the content of specific and total sugars among different studies can be ascribed to environmental factors, geographic origin, genetic variation and different analytical met.

\subsection{Mineral content}

Seven minerals were determined in all samples. Mineral contents were determined to vary widely depending on the different species. Table 4 shows that medicinal plants content considerably $\mathrm{Ca}$, $\mathrm{Na}, \mathrm{K}, \mathrm{Fe}, \mathrm{Mn}, \mathrm{Zn}$ and $\mathrm{Mg}$. The highest mineral concentrations were measured between $1.48 \pm 0.21$ and $4.67 \pm 0.17 \mu \mathrm{g} \mathrm{g}^{-1} \mathrm{Ca}$, $8.65 \pm 1.04$ and $18.45 \pm 0.12 \mu \mathrm{g} \mathrm{g}^{-1} \mathrm{Na}, 245.12 \pm 0.46$ and $586.64 \pm 2.76 \mu \mathrm{g} \mathrm{g}^{-1} \mathrm{~K}, 0.01 \pm 0.007$ and $0.14 \pm 0.04 \mu \mathrm{g} \mathrm{g}^{-1} \mathrm{Fe}$, $0.04 \pm 0.005$ and $0.21 \pm 0.04 \mu \mathrm{g} \mathrm{g}^{-1} \mathrm{Mn}, 0.05 \pm 0.02$ and $0.17 \pm$ $0.02 \mu \mathrm{g} \mathrm{g}^{-1} \mathrm{Zn}$ and $0.07 \pm 0.01$ and $0.18 \mu \mathrm{g} \mathrm{g}^{-1} \mathrm{Mg}$. Concentration of various elements analysed in the present work decreases in the order: $\mathrm{K}>\mathrm{Na}>\mathrm{Ca}>\mathrm{Mg}>\mathrm{Mn}>\mathrm{Zn}>\mathrm{Fe}$. The differences in the concentration of the various elements within the different plants is attributed to the preferential absorbability of a particular plant for the corresponding element and the mineral composition the soil in which the plant grows as well as its surrounding climatologically conditions. The mineral analysis of plant samples extracts revealed the presence of macronutrients $(\mathrm{Ca}, \mathrm{K}, \mathrm{Mg}$ and $\mathrm{Na}$ ) and micronutrients $(\mathrm{Zn}, \mathrm{Cu}, \mathrm{Mn}$ and $\mathrm{Fe}$ ). These components are essential for the physiological functions of organisms. Indeed, the need for mineral content is necessary to avoid metal deficiency syndrome like rickets and clarification of bones as a result of calcium deficiency (Yisa \& Jimoh, 2010). Distorted enzymatic activity and poor electrolyte balance of the blood fluid are related to inadequate $\mathrm{Na}, \mathrm{Mg}, \mathrm{K}$ and $\mathrm{Zn}$ as they are most required elements of living cells (Smith, 2009). In fact, $\mathrm{Na}, \mathrm{K}$ and $\mathrm{Ca}$ play an important role in the electrophysiology of cardiac tissue in the treatment of cardiovascular diseases (Oumarou, et al., 2013). In addition, iron is an important element for human body and plays a role in oxygen and electron transfer. It is necessary for the formation of haemoglobin. $\mathrm{Zn}$ is an essential metal for the normal functioning of various enzyme systems. Mn is found both as a structural component of some enzymes and as an activator of others (Kongkachuichai, et al., 2015). Although the presences of micro and macro nutriments are essential for a good body metabolism, their high intake may be harmful (Oumarou, et al., 2013). Moreover, one important factor for the formation of active constituents in medicinal plants is the trace elements because they are known to play an important role in plant metabolism. Although there are reports in the literature on the trace elements content in plants, we are still far from the point of knowing exactly the mechanisms of action and the formation of active constituents for ech medicinal plants. Major and Minor elements have very important functions and it is believed a key component of proteins such as haemoprotein and haemoglobin which play role in biochemical functions and essential enzyme system even in low doses (Erden \& K1lıç, 2013).

Table 3: Sugar Content of Plant Samples $(\mu \mathrm{g} / \mathrm{G})$

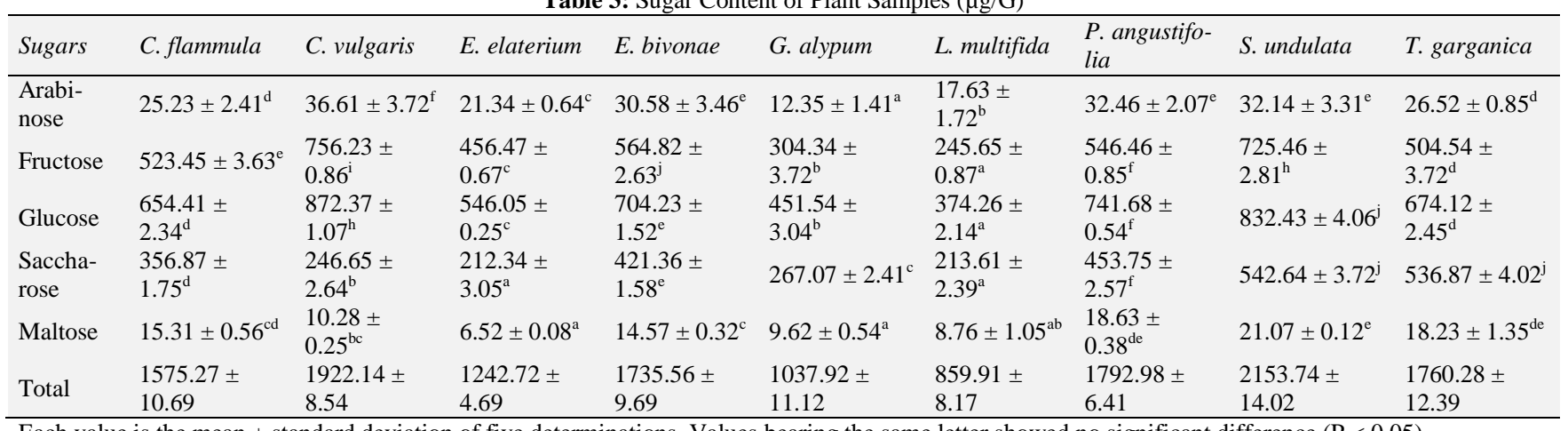

Each value is the mean \pm standard deviation of five determinations, Values bearing the same letter showed no significant difference $(\mathrm{P}<0.05)$.

Table 4: Mineral Content of Plant Samples

\begin{tabular}{|c|c|c|c|c|c|c|c|c|c|}
\hline $\begin{array}{l}\text { Miner- } \\
\text { als }\end{array}$ & C. flammula & C. vulgaris & E. elaterium & E. bivonae & G. alypum & L. multifida & $\begin{array}{l}\text { P. angustifo- } \\
\text { lia }\end{array}$ & S. undulata & T. garganica \\
\hline $\mathrm{Ca}$ & $3.54 \pm 0.21^{\mathrm{c}}$ & $2.56 \pm 0.12^{b}$ & $4.42 \pm 0.15^{\mathrm{d}}$ & $1.74 \pm 0.06^{\mathrm{a}}$ & $3.12 \pm 0.08^{b c}$ & $2.86 \pm 0.31^{b c}$ & $4.67 \pm 0.17^{\mathrm{c}}$ & $3.34 \pm 0.11^{\mathrm{c}}$ & $1.48 \pm 0.21^{\mathrm{a}}$ \\
\hline $\mathrm{Na}$ & $9.54 \pm 1.03^{\mathrm{a}}$ & $15.21 \pm 2.34^{\mathrm{b}}$ & $17.32 \pm 0.23^{\mathrm{c}}$ & $12.54 \pm 0.32^{b}$ & $13.64 \pm 0.51^{b}$ & $10.07 \pm 0.05^{\mathrm{a}}$ & $18.45 \pm 0.12^{\mathrm{c}}$ & $14.07 \pm 0.34^{b}$ & $8.65 \pm 1.04^{\mathrm{a}}$ \\
\hline K & $\begin{array}{l}342.2 \pm \\
3.45^{\mathrm{c}}\end{array}$ & $\begin{array}{l}534.32 \pm \\
4.56^{\mathrm{g}}\end{array}$ & $\begin{array}{l}562.47 \pm \\
1.54^{\mathrm{h}}\end{array}$ & $\begin{array}{l}415.23 \pm \\
0.07^{\mathrm{e}}\end{array}$ & $\begin{array}{l}361.02 \pm \\
0.41^{\mathrm{d}}\end{array}$ & $\begin{array}{l}308.45 \pm \\
0.32^{\text {ab }}\end{array}$ & $\begin{array}{l}245.12 \pm \\
0.46^{\mathrm{a}}\end{array}$ & $\begin{array}{l}586.64 \pm \\
2.76^{i}\end{array}$ & $\begin{array}{l}451.65 \pm \\
4.12^{\mathrm{f}}\end{array}$ \\
\hline $\mathrm{Fe}$ & $\begin{array}{l}0.08 \pm \\
0.001^{\mathrm{e}}\end{array}$ & $0.05 \pm 0.01^{\mathrm{c}}$ & $0.07 \pm 0.01^{\mathrm{de}}$ & $0.14 \pm 0.04^{\mathrm{g}}$ & $0.03 \pm 0.01^{\mathrm{b}}$ & $0.02 \pm 0.002^{\mathrm{ab}}$ & $0.11 \pm 0.01^{\mathrm{f}}$ & $\begin{array}{l}0.06 \pm \\
0.004^{\text {cd }}\end{array}$ & $0.01 \pm 0.007^{\mathrm{a}}$ \\
\hline Mn & $0.21 \pm 0.04^{\mathrm{g}}$ & $0.12 \pm 0.01^{\mathrm{c}}$ & $0.05 \pm 0.001^{\mathrm{a}}$ & $0.17 \pm 0.01^{\mathrm{e}}$ & $0.04 \pm 0.005^{\mathrm{a}}$ & $0.13 \pm 0.03^{\mathrm{c}}$ & $0.2 \pm 0.03^{\mathrm{f}}$ & $0.09 \pm 0.01^{\mathrm{b}}$ & $0.15 \pm 0.03^{\mathrm{d}}$ \\
\hline $\mathrm{Mg}$ & $0.17 \pm 0.02^{\mathrm{e}}$ & $0.13 \pm 0.03^{\text {cd }}$ & $0.07 \pm 0.01^{\mathrm{a}}$ & $0.12 \pm 0.03^{\mathrm{bc}}$ & $0.14 \pm 0.04^{\mathrm{d}}$ & $0.18 \pm 0.04^{f}$ & $0.11 \pm 0.05^{\mathrm{b}}$ & $0.12 \pm 0.01^{\mathrm{bc}}$ & $0.18 \pm 0.04^{f}$ \\
\hline
\end{tabular}

Mineral contents expressed as milligrams per $1 \mathrm{~g}$ of dry weight. Each value is the mean \pm standard deviation of five determinations, Values bearing the same letter showed no significant difference $(\mathrm{P}<0.05)$.

\subsection{Vitamin and phytosterol contents of the plant sam- ples}

Recently, walnut has been considered as natural functional food of high economic interest due to its nutritional and medicinal benefits (Singh, et al., 2014). Plants produce large amounts of vitamins to facilitate resistance to the oxidative stresses. Particularly vitamin
$\mathrm{E}$ and vitamin $\mathrm{C}$ with potent antioxidant activities have recently received a great deal of attention because of their action on immunity and disease etiology. Liposoluble vitamin and phytosterol concentrations of the samples are depicted in Table 5. Four vitamins were determined in all samples. Vitamins are compounds that cannot be synthesized by humans and thus need to be taken up in the diet. They have a complex biochemistry and play an essen- 
tial role in human nutrition and health. Vitamin contents were determined to vary widely depending on the different species. Among vegetables, vitamin D was the dominant vitamin. Plants contain a wide range of vitamins that are essential not only for human metabolism but also for plants, because of their redox chemistry and role as cofactors, and some of them also have strong antioxidant potential. The antioxidant vitamins that have been the focus of most attention in plants are retinol (vitamin A), $\alpha$-Tocopherol (vitamin E), Vitamin K and to cochromanols (vitamin E, including both tocopherols and tocotrienols). The vitamin $\mathrm{D}$ levels in the investigated vegetables ranged from $2.69 \pm 0.21$ to $7.41 \pm 0.35 \mu \mathrm{g} \mathrm{g}^{-1}$ of dry matter. Higher levels were observed in G. alypum $\left(7.41 \pm 0.35 \mu \mathrm{g} \mathrm{g}^{-1}\right)$, followed by E. bivonae $(5.84 \pm$ $\left.0.26 \mu \mathrm{g} \mathrm{g}^{-1}\right)$, C. flammula $\left(4.54 \pm 0.23 \mu \mathrm{g} \mathrm{g}^{-1}\right)$, L. multifida $(4.07 \pm$ $\left.0.12 \mu \mathrm{g} \mathrm{g}^{-1}\right)$, P. angustifolia $\left(3.66 \pm 0.21 \mu \mathrm{g} \mathrm{g}^{-1}\right)$, C. vulgaris $(3.57$ $\left.\pm 0.16 \mu \mathrm{g} \mathrm{g}^{-1}\right), T$. garganica $\left(3.56 \pm 0.22 \mu \mathrm{g} \mathrm{g}^{-1}\right)$, S. undulata $(2.78$ $\left.\pm 0.12 \mu \mathrm{g} \mathrm{g}^{-1}\right)$ and E. elaterium $\left(2.69 \pm 0.21 \mu \mathrm{g} \mathrm{g}^{-1}\right)$. The highest values of vitamin $\mathrm{K}$, Retinol and $\alpha$-tocopherol were established in E. bivonae leave $\left(4.12 \pm 0.14 \mu \mathrm{g} \mathrm{g}^{-1}\right)$, L. multifida $(2.11 \pm 0.01 \mu \mathrm{g}$ $\left.\mathrm{g}^{-1}\right)$ and $T$. garganica $(0.64 \pm 0.08 \mu \mathrm{g}$ g-1), respectively. Vitamin $\mathrm{D}$ content of the groups was higher than the other vitamins. This vitamin deficiency is a global concern with estimates ranging from one billion to more than three billion people affected worldwide (Palacios \& Gonzalez, 2014). An adequate vitamin D supply is essential to control calcium homeostasis and bone turnover and thereby crucial for bone health and the prevention of osteoporosis (Holick, 2007). In other hand, vitamin K has originally emerged from a pure hemostasiological cofactor required to activate clotting factors, it is also a key factor in the regulation of bone and soft tissue calcification based on the anti-calcific property of vita$\min \mathrm{K}$ due to its ability to activate matrix-Gla protein (MGP) (Brandenburg, et al., 2015). Data from epidemiological studies have pointed out to an important role of Vitamin $\mathrm{K}$ as a potentially protective factor for cardiovascular health. The past few years, there has been an interest in fat soluble compounds such as retinol, $\alpha$-tocopherol due to their beneficial effects on human health. In addition, retinol is a part of a group of fat-soluble and antioxidant vitamins, whose members include retinol and carotenoids; the antioxidant and anti-inflammatory capacities (Higuchi, et al., 2015). However, in recent years, the importance of tocopherols has been increasingly recognized due to the emerging knowledge of their health benefits (Orabi \& Abdelhamid, 2014). Antioxidants, such as the tocopherols have had their superb antioxidant activities confirmed in different food systems (Jayasinghe, et al., 2013). (Abdallah, et al., 2015) reported that tocopherols have numerous beneficial properties, such as anti-inflammatory and antiproliferative effects in human cancer.

Table 5: Vitamins and Phytosterols Contents in Plant Samples $(\mu \mathrm{g} / \mathrm{G})$

\begin{tabular}{|c|c|c|c|c|c|c|c|c|c|}
\hline $\begin{array}{l}\text { Vitamins \& } \\
\text { phytosterols }\end{array}$ & C. flammula & C. vulgaris & E. elaterium & E. bivonae & G. alypum & L. multifida & P. angustifolia & S. undulata & T. garganica \\
\hline Vitamin K & $1.23 \pm 0.13^{\mathrm{b}}$ & $2.41 \pm 0.01^{\mathrm{d}}$ & $3.07 \pm 0.06^{\mathrm{g}}$ & $4.12 \pm 0.14^{\mathrm{i}}$ & $0.87 \pm 0.04^{\mathrm{a}}$ & $2.45 \pm 0.07^{\mathrm{e}}$ & $3.67 \pm 0.17^{\mathrm{h}}$ & $2.82 \pm 0.01^{\mathrm{f}}$ & $1.75 \pm 0.11^{\mathrm{c}}$ \\
\hline Retinol & $0.43 \pm 0.01^{b}$ & $1.03 \pm 0.07^{\mathrm{g}}$ & $0.57 \pm 0.05^{\mathrm{d}}$ & $0.85 \pm 0.02^{\mathrm{f}}$ & $0.36 \pm 0.07^{\mathrm{a}}$ & $2.11 \pm 0.01^{\mathrm{i}}$ & $1.76 \pm 0.02^{\mathrm{h}}$ & $0.63 \pm 0.04^{\mathrm{e}}$ & $0.53 \pm 0.02^{b}$ \\
\hline Vitamin D & $4.54 \pm 0.23^{\mathrm{f}}$ & $3.57 \pm 0.16^{\mathrm{c}}$ & $2.69 \pm 0.21^{\mathrm{a}}$ & $5.84 \pm 0.26^{\mathrm{g}}$ & $7.41 \pm 0.35^{\mathrm{h}}$ & $4.07 \pm 0.12^{\mathrm{e}}$ & $3.66 \pm 0.21^{\mathrm{d}}$ & $2.78 \pm 0.12^{b}$ & $3.56 \pm 0.22^{\mathrm{c}}$ \\
\hline$\alpha$-Tocopherol & $0.52 \pm 0.02^{\mathrm{f}}$ & $0.34 \pm 0.003^{c}$ & $0.09 \pm 0.002^{\mathrm{a}}$ & $0.57 \pm 0.03^{\mathrm{g}}$ & $0.08 \pm 0.002^{\mathrm{a}}$ & $0.24 \pm 0.001^{b}$ & $0.36 \pm 0.04^{\mathrm{d}}$ & $0.41 \pm 0.01^{\mathrm{e}}$ & $0.64 \pm 0.08^{h}$ \\
\hline Ergosterol & $3.06 \pm 0.05^{\mathrm{g}}$ & $2.42 \pm 0.11^{\mathrm{e}}$ & $1.86 \pm 0.07^{\mathrm{b}}$ & $2.07 \pm 0.06^{\mathrm{c}}$ & $3.45 \pm 0.13^{\mathrm{i}}$ & $3.22 \pm 0.05^{\mathrm{h}}$ & $2.35 \pm 0.08^{\mathrm{d}}$ & $1.57 \pm 0.03^{\mathrm{a}}$ & $2.47 \pm 0.05^{\mathrm{f}}$ \\
\hline Stigmasterol & $21.34 \pm 0.71^{\mathrm{c}}$ & $10.23 \pm 0.08^{\mathrm{a}}$ & $17.34 \pm 0.36^{b}$ & $25.74 \pm 2.41^{\mathrm{d}}$ & $12.32 \pm 0.61^{\mathrm{a}}$ & $9.75 \pm 0.06^{\mathrm{a}}$ & $8.72 \pm 1.01^{\mathrm{a}}$ & $15.36 \pm 0.42^{b}$ & $11.62 \pm 1.04^{\mathrm{a}}$ \\
\hline$\beta$-Sitosterol & $18.23 \pm 0.37^{\mathrm{d}}$ & $54.08 \pm 2.58^{\mathrm{a}}$ & $7.52 \pm 0.41^{\mathrm{b}}$ & $36.46 \pm 3.04^{\mathrm{g}}$ & $21.35 \pm 1.34^{\mathrm{f}}$ & $40.21 \pm 2.12^{\mathrm{h}}$ & $15.43 \pm 0.07^{c}$ & $20.87 \pm 0.31^{\mathrm{e}}$ & $5.26 \pm 0.21^{\mathrm{a}}$ \\
\hline
\end{tabular}

Plant sterols and plant stanols, collectively referred to as phytosterols, are natural constituents of plant-based foods which have been shown to lower serum total and low density lipoprotein cholesterol when added to the diets of humans (Abdallah, et al., 2015). Over 100 different phytosterols have been identified, of which the most common include campesterol, b-sitosterol, stigmasterol, brassi-casterol, and D5-avenasterol. Foods naturally rich in phytosterols include vegetable oils, legumes, nuts, seeds, and whole grains. The analysis showed a considerable variation of plant sterol content in different vegetables. The ergosterol amount of plant samples ranged from $1.57 \pm 0.03$ to $3.45 \pm 0.13 \mu \mathrm{g} \mathrm{g}^{-1}$. The highest levels were observed in G. alypum $\left(3.45 \pm 0.13 \mu \mathrm{g} \mathrm{g}^{-1}\right)$, followed by L. multifida $\left(3.22 \pm 0.05 \mu \mathrm{g} \mathrm{g}^{-1}\right)$, C. flammula $(3.06 \pm 0.05 \mu \mathrm{g}$ $\left.\mathrm{g}^{-1}\right), T$. garganica $\left(2.47 \pm 0.05 \mu \mathrm{g} \mathrm{g}^{-1}\right)$, C. vulgaris $(2.42 \pm 0.11 \mu \mathrm{g}$ $\left.\mathrm{g}^{-1}\right), P$. angustifolia $(2.35 \pm 0.08)$, E. bivonae $\left(2.07 \pm 0.06 \mu \mathrm{g} \mathrm{g}^{-1}\right)$, E. elaterium $\left(1.86 \pm 0.07 \mu \mathrm{g} \mathrm{g}^{-1}\right)$ and $S$. undulata $(1.57 \pm 0.03 \mu \mathrm{g}$ $\left.\mathrm{g}^{-1}\right)$. Total plant stigmasterol in the 9 plants ranged from $8.72 \pm$

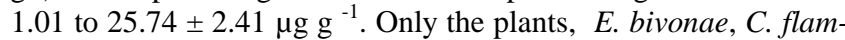
mula, E. elaterium and $S$. undulata, had a content of sterols higher than $15 \mu \mathrm{g} \mathrm{g}^{-1}$, the value being $25.74 \pm 2.41 \mu \mathrm{g} \mathrm{g}^{-1}, 21.34 \pm 0.71$ $\mu \mathrm{g} \mathrm{g}^{-1}, 17.34 \pm 0.36 \mu \mathrm{g} \mathrm{g}^{-1}$ and $15.36 \pm 0.42 \mu \mathrm{g} \mathrm{g}^{-1}$, respectively. The lowest plant stigmasterol contents were found in G. alypum $\left(12.32 \pm 0.61 \mu \mathrm{g} \mathrm{g}^{-1}\right) T$. garganica $\left(11.62 \pm 1.04 \mu \mathrm{g} \mathrm{g}^{-1}\right), C$. vul garis $\left(10.23 \pm 0.08 \mu \mathrm{g} \mathrm{g}^{-1}\right)$, L. multifida $\left(9.75 \pm 0.06 \mu \mathrm{g} \mathrm{g}^{-1}\right)$ and $P$. angustifolia $\left(8.72 \pm 1.01 \mu \mathrm{g} \mathrm{g}^{-1}\right)$. The concentration of the $\beta$ Sitosterol sterol varied among species. Thus, $C$. vulgaris contained $54.08 \pm 2.58$, L. multifida $(40.21 \pm 2.12)$, E. bivonae $(36.46 \pm 3.04$ $\left.\mu \mathrm{g} \mathrm{g}^{-1}\right)$, G. alypum $\left(21.35 \pm 1.34 \mu \mathrm{g} \mathrm{g}^{-1}\right)$, S. undulata $(20.87 \pm$ $\left.0.31 \mathrm{\mu g} \mathrm{g}^{-1}\right)$, C. flammula $\left(18.23 \pm 0.37 \mu \mathrm{g} \mathrm{g}^{-1}\right)$ and P. angustifolia $\left(15.43 \pm 0.07 \mathrm{\mu g} \mathrm{g}^{-1}\right)$ whereas $T$. garganica and E. elaterium showed $5.26 \pm 0.21$ and $7.52 \pm 0.41 \mu \mathrm{g} \mathrm{g}^{-1}$, respectively. $\beta$ sitosterol (plant sterols) recently has received increased attention due to their capability to inhibit cholesterol intestinal absorption, resulting in lowering serum total plasma cholesterol and lowdensity lipoprotein levels.

\subsection{Antioxidant activity}

DPPH method, the ABTS radical scavenging method is one of the most extensively used antioxidant assays for plant samples. Antioxidants used in foods are chemical compounds that are capable to donate hydrogen radicals, so they could minimize rancidity and lipid peroxidation in food products. They enhance the shelf life of lipid-rich products without any damage to sensory or nutritional quality. Several assay methods have been developed and applied to screen and evaluate the total antioxidant activity of these plants extracts. Thus, two commonly applied assays, differing in their working principles, were employed as a part of our investigation. Namely, antioxidant properties of the examined plants were determined as free radical scavenging ability, using DPPH method and the $\mathrm{ABTS}^{-+}$radical cation. Results for DPPH test in our research were expressed as $\mathrm{IC}_{50} \mathrm{DPPH}$ with the higher $\mathrm{IC}_{50} \mathrm{DPPH}$ values indicating lower antioxidant capacity. The $\mathrm{IC}_{50}$ value is defined as the concentration of plant extract with $50 \%$ free radical scavenging potential. Quantitative results concerning ABTS radical scavenging capacity are expressed in mmol of Trolox equivalents (TE) per g of dry weight (DW). The comparison of mean DPPH scavenging activity of plant samples is presented in the Fig. 4. All extracts were capable of scavenging hydrogen peroxide. Total antioxidant activity, measured by the DPPH method, varied between $51.23 \%$ and $96.41 \%$. Among the samples, the P. angustifolia and $T$. garganica had very high antioxidant capacity in methanol extract (81\% and $77 \%$, respectively). On the one hand, the high antioxidant activity in methanol extracts of these families could be related to the high phenolic compounds content showed by these species. In contrast, E. elaterium and $S$. undulata extracts had the lowest DPPH radical scavenging activity. A differently of the power of the DPPH radical scavenging (*P $<0.05$ ) was found between the plant samples and the standards used. $\mathrm{IC}_{50} \mathrm{DPPH}$ of the investigated plants ranged from $256.07 \pm 2.07 \mu \mathrm{g} / \mathrm{ml}$ to 102.31 $\mu \mathrm{g} / \mathrm{ml}$ for $102.31 \pm 2.45$ of extract (Table. 6). Methanolic fraction 
of $\mathrm{P}$. angustifolia and of $\mathrm{C}$. tunisiatica, also have high scavenging capacities. $\mathrm{IC}_{50}$ values of two families (Ranunculaceae and Asclepiadaceae) were lower $(\mathrm{P}<0.05)$ than that obtained for ascorbic acid, which suggests that these fractions have the most potent hydrogen peroxide scavenging capacity. In contrast, E. elaterium and $L$. multifida extracts had the lowest DPPH radical scavenging activity. $\mathrm{IC}_{50}$ values of four plants ( $P$. angustifolia, $C$. flammula, $E$. bivonae and $T$. garganica) were lower $(\mathrm{P}<0.05)$ than that obtained for ascorbic acid and BHT, which suggests that these plants have the most potent DPPH radical scavenging capacity. This extract can be considered to have a high percentage of inhibition of $\mathrm{DPPH} \cdot$, because after completing the reaction, the final solution always possessed some yellowish color. It is clear from these results that on the basis of scavenging activity against DPPH radical of the species, varieties are classified according to the following order: P. angustifolia $>$ T. garganica $>$ G. alypum $>$ L. multifida $>$ C. flammula $>$ E. bivonae $>$ C. vulgaris $>$ S. undulata $>$ E. elateri$u m$. The reduction of DPPH radical by the plant extracts has been attributed by several authors, at the presence of phenolic compounds which yield easily to reduce protons. Their capacity varies from a compound to another and there is a synergy between them and/or other present constituents in these species (Bourgou, et al., 2008). Antioxidant activities evaluated by the ABTS radical scavenging capacity of methanol extracts of the samples are presented in Table 6. Results for ABTS test in our research were expressed as $\mathrm{IC}_{50}$ with the higher $\mathrm{IC}_{50}$ values indicating lower antioxidant capacity. The leaves of $P$. angustifolia showed higher antioxidant activity in methanol extracts $(9.4 \pm 0.76 \mu \mathrm{g}$ TE/g DW) than in $E$. elaterium $(45.64 \pm 3.04 \mu \mathrm{g}$ TE/g DW). Our results revealed also that the studied medicinal herbs exhibit clearly a higher antioxidant activity and contain significantly more phenolics than the common vegetables and fruits (nutritional plants). In addition, $P$. angustifolia, $C$. vulgaris and C. flammula were also shown to possess high antioxidant properties in both the ABTS (10.04 \pm $1.23,11.23 \pm 1.03$ and $13.84 \pm 2.14 \mathrm{mg}$ TE/ g DW) assays. In contrast, the lowest scavenging capacity was found in E. elaterium, E. bivonae and G. alypum families. However, these plants, although having low total polyphenol content. P. angustifolia, which exhibited the highest scavenging of $\mathrm{DPPH}^{+}$and $\mathrm{ABTS}^{*+}$ ability.

Table 6: Antioxidant Activity of Plant Samples by DPPH and ABTS Assay Radical Scavenging Assay

\begin{tabular}{lll}
\hline Plant samples & $\mathrm{IC}_{50}(\mu \mathrm{g} / \mathrm{ml})$ & \\
& $\mathrm{DPPH}$ & ABTS \\
\hline C. flammula & $123.56 \pm 1.46^{\mathrm{d}}$ & $13.84 \pm 2.14^{\mathrm{g}}$ \\
C. vulgaris & $132.14 \pm 0.87^{\mathrm{e}}$ & $10.04 \pm 1.23^{\mathrm{d}}$ \\
E. elaterium & $256.07 \pm 2.07^{\mathrm{g}}$ & $45.64 \pm 3.04^{\mathrm{k}}$ \\
E. bivonae & $123.74 \pm 1.08^{\mathrm{d}}$ & $22.42 \pm 0.85^{\mathrm{j}}$ \\
G. alypum & $112.32 \pm 1.42^{\mathrm{bc}}$ & $18.65 \pm 1.21^{\mathrm{i}}$ \\
L. multifida & $111.09 \pm 2.14^{\mathrm{bc}}$ & $13.45 \pm 1.21^{\mathrm{f}}$ \\
P. angustifolia & $102.31 \pm 2.45^{\mathrm{b}}$ & $9.4 \pm 0.76^{\mathrm{c}}$ \\
S. undulata & $142.12 \pm 3.05^{\mathrm{f}}$ & $15.07 \pm 1.78^{\mathrm{h}}$ \\
T. garganica & $114.45 \pm 3.06^{\mathrm{c}}$ & $11.23 \pm 1.03^{\mathrm{e}}$ \\
Ascorbic acid & $60.45 \pm 1.42^{\mathrm{a}}$ & $4.12 \pm 1.04^{\mathrm{a}}$ \\
BHT & $90.56 \pm 0.76^{\mathrm{a}}$ & $6.24 \pm 0.43^{\mathrm{b}}$ \\
\hline Values are mean & &
\end{tabular}

Values are mean of three independent determinations $(\mathrm{n}=3) ; \pm$ standard deviation, Values followed by different superscript in each line are significantly different $(\mathrm{P}<0.05)$.

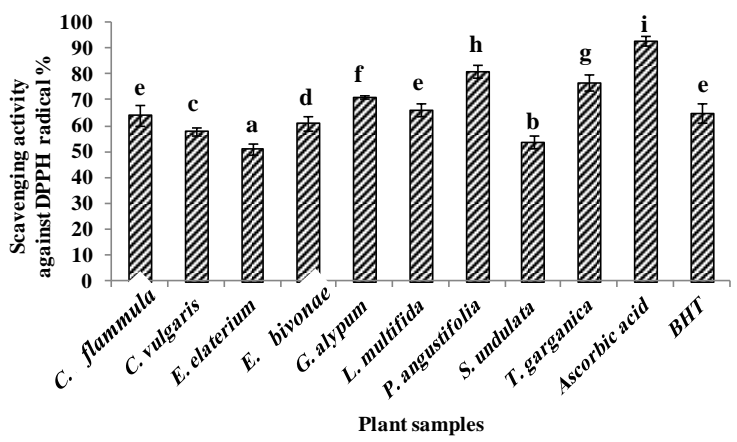

Fig. 3: Mean Antioxidant Activity against DPPH Radical of Plant Extracts at $1 \mathrm{Mg} / \mathrm{Ml}$ and Standards at $50 \mu \mathrm{g} / \mathrm{Ml}$. DPPH: 1, 1-Diphenyl 1-2-
Picrylhydrazyl. Values Bearing the Same Letter Showed No Significant Difference $(\mathrm{P}<0.05)$

\section{Conclusion}

The processing of plant foods results in the production of byproducts that are rich sources of bioactive substances, including polyphenols. The beneficial effects derived from these compounds have been attributed to their antioxidant activity. The results of the present work revealed that all of the investigated herbal species were rich in phenolic constituents and demonstrated satisfying antioxidant activity measured by two different methods used. Based on this study, most medicinal plants available from southern part of Tunisian contain small to moderate amounts of macronutrients, vitamins, sugar, flavonoids and minerals Our systematically comparative investigation of 9 selected plants from the locality of Gafsa has, however, singled out some of the species as the most potent antioxidants. The plants showing the highest antioxidant activities were $P$. angustifolia, $T$. garganica, G. alypum and $L$ multifida. $P$. angustifolia belongs to Asclepiadaceae family demonstrated by far the most potent antioxidant activity, as well as total phenolic and flavonoids content.

\section{Acknowledgement}

This work was supported by the research unit biodiversity and aquatic ecosystems and in the Faculty of sciences of Sfax. Thanks are due to Dr. Fawzi Makni for his help in verifying the quality of the manuscript. This study was funded by research Unit UR 11 ES 72/Biodiversity and Aquatic Ecosystems

\section{References}

[1] Abdallah, I. B., Tlili, N., Martinez-Force, E., Rubio, A. G. P., Perez-Camino, M. C., Albouchi, A., \& Boukhchina, S. (2015). Content of carotenoids, tocopherols, sterols, triterpenic and aliphatic alcohols, and volatile compounds in six walnuts (Juglans regia L.) varieties. Food chemistry, 173, 972-978. http://dx.doi.org/10.1016/j.foodchem.2014.10.095.

[2] Agarwal, A., Durairajanayagam, D., \& du Plessis, S. S. (2014). Utility of antioxidants during assisted reproductive techniques: an evidence based review. Reproductive Biology and Endocrinology, 12, 1. http://dx.doi.org/10.1186/1477-7827-12-112.

[3] Akhtar, S., Ismail, T., Fraternale, D., \& Sestili, P. (2015). Pomegranate peel and peel extracts: Chemistry and food features. Food chemistry, 174, 417-425 http://dx.doi.org/10.1016/j.foodchem.2014.11.035.

[4] Boulanouar, B., Abdelaziz, G., Aazza, S., Gago, C., \& Miguel, M. G. (2013). Antioxidant activities of eight Algerian plant extracts and two essential oils. Industrial Crops and Products, 46, 85-96. http://dx.doi.org/10.1016/j.indcrop.2013.01.020.

[5] Bourgou, S., Ksouri, R., Bellila, A., Skandrani, I., Falleh, H., \& Marzouk, B. (2008). Phenolic composition and biological activities of Tunisian Nigella sativa L. shoots and roots. C R Biol, 331, 48-55. http://dx.doi.org/10.1016/j.crvi.2007.11.001.

[6] Bragança, V. L. C., Melnikov, P., \& Zanoni, L. Z. (2011). Trace elements in different brands of yerba mate tea. Biol Trace Elem Res, 144, 1197-1204. http://dx.doi.org/10.1007/s12011-011-9056-3.

[7] Brandenburg, V. M., Schurgers, L. J., Kaesler, N., Püsche, K., van Gorp, R. H., Leftheriotis, G., Reinartz, S., Koos, R., \& Krüger, T. (2015). Prevention of vasculopathy by vitamin K supplementation: can we turn fiction into fact? Atherosclerosis, 240, 10-16. http://dx.doi.org/10.1016/j.atherosclerosis.2015.02.040.

[8] Bravo, L. (1998). Polyphenols: chemistry, dietary sources, metabolism, and nutritional significance. Nutrition reviews, 56, 317-333. http://dx.doi.org/10.1111/j.1753-4887.1998.tb01670.x.

[9] Broadhurst, R. B., \& Jones, W. T. (1978). Analysis of condensed tannins using acidified vanillin. Journal of the Science of Food and Agriculture, 29 , http://dx.doi.org/10.1002/jsfa.2740290908

[10] Campa, C., Coslovi, A., Flamigni, A., \& Rossi, M. (2006). Overview on advances in capillary electrophoresis-mass spectrometry of carbohydrates: A tabulated review. Electrophoresis, 27, 2027-2050. http://dx.doi.org/10.1002/elps.200500960. 
[11] Cavero, R., Akerreta, S., \& Calvo, M. (2013). Medicinal plants used for dermatological affections in Navarra and their pharmacological validation. Journal of ethnopharmacology, 149, 533-542. http://dx.doi.org/10.1016/j.jep.2013.07.012

[12] Cordero-De-Los-Santos, M., Osuna-Castro, J., Borodanenko, A., \& Paredes-López, O. (2005). Physicochemical and functional characterisation of amaranth (Amaranthus hypochondriacus) protein isolates obtained by isoelectric precipitation and micellisation. Food science and technology international, 11, 269-280. http://dx.doi.org/10.1177/1082013205056491.

[13] Cuoco, G., Mathe, C., \& Vieillescazes, C. (2014). Liquid chromatographic analysis of flavonol compounds in green fruits of three Rhamnus species used in Stil de grain. Microchemical Journal, 115 130-137. http://dx.doi.org/10.1016/j.microc.2014.03.006

[14] De Azevedo, A. (2013). IL Cortiço: Simonelli Editore.

[15] Djeridane, A., Yousfi, M., Nadjemi, B., Boutassouna, D., Stocker, P., \& Vidal, N. (2006). Antioxidant activity of some Algerian medicinal plants extracts containing phenolic compounds. Food chemistry, 97,

$654-660$ http://dx.doi.org/10.1016/j.foodchem.2005.04.028.

[16] Dogan, Y., Ugulu, I., \& Baslar, S. (2010). Turkish Red Pine as a biomonitor: a comparative study of the accumulation of trace elements in the needles and bark. Ekoloji, 19, 88-96. http://dx.doi.org/10.5053/ekoloji.2010.7512.

[17] Dubois, M., Gilles, K. A., Hamilton, J. K., Rebers, P., \& Smith, F. (1956). Colorimetric method for determination of sugars and related substances. Analytical chemistry, 28, 350-356. http://dx.doi.org/10.1021/ac60111a017.

[18] Emim, J. A. d. S., Souccar, C., Castro, M. S. d. A., Godinho, R. O. Cezari, M. H. S., Juliano, L., \& Lapa, A. J. (2000). Evidence for activation of the tissue kallikrein-kinin system in nociceptive transmission and inflammatory responses of mice using a specific enzyme inhibitor. British Journal of Pharmacology, 130, 1099-1107. http://dx.doi.org/10.1038/sj.bjp.0703362.

[19] Erden, P. E., \& Kılıç, E. (2013). A review of enzymatic uric acid biosensors based on amperometric detection. Talanta, 107, 312-323. http://dx.doi.org/10.1016/j.talanta.2013.01.043.

[20] Erdogan, T., Gonenc, T., Demirci, B., \& Kivçak, B. (2014). Determination of fatty acid and essential oil constituents and biological activities on Ranunculus pedatus subsp. pedatus. Asian Journal of Chemistry, 26, 2156.

[21] Ferrandiz, M. L., \& Alcaraz, M. J. (1991). Anti-inflammatory activity and inhibition of arachidonic acid metabolism by flavonoids. Agents Actions, 32, 283-288. http://dx.doi.org/10.1007/BF01980887.

[22] Garcia-Closas, R., Agudo, A., Gonzalez, C. A., \& Riboli, E. (1998) Intake of specific carotenoids and flavonoids and the risk of lung cancer in women in Barcelona, Spain.

[23] Harvey, D. J. (2009). Analysis of carbohydrates and glycoconjugates by matrix-assisted laser desorption/ionization mass spectrometry: An update for 2003-2004. Mass spectrometry reviews, 28 , 273-361. http://dx.doi.org/10.1002/mas.20192.

[24] Haslam, E. (1996). Natural polyphenols (vegetable tannins) as drugs: possible modes of action. Journal of natural products, 59, 205-215. http://dx.doi.org/10.1021/np960040+.

[25] Higuchi, K., Saito, I., Maruyama, K., Eguchi, E., Mori, H., Tanno, S., Sakurai, S., Kishida, T., Nishida, W., \& Osawa, H. (2015). Associations of serum $\beta$-carotene and retinol concentrations with insulin resistance: The Toon Health Study. Nutrition, 31, 975-980. http://dx.doi.org/10.1016/j.nut.2015.02.015.

[26] Holick, M. F. (2007). Vitamin D deficiency. New England Journal of $\quad$ Medicine, 266-281. http://dx.doi.org/10.1056/NEJMra070553.

[27] Hou, D.-X. (2003). Potential mechanisms of cancer chemoprevention by anthocyanins. Current molecular medicine, 3, 149-159. http://dx.doi.org/10.2174/1566524033361555.

[28] Ibrahim, M. M., \& Damasceno, A. (2012). Hypertension in developing countries. The Lancet, 380, 611-619. http://dx.doi.org/10.1016/S0140-6736(12)60861-7.

[29] Jayasinghe, C., Gotoh, N., \& Wada, S. (2013). Prooxidant/antioxidant behaviours of ascorbic acid, tocopherol, and plant extracts in n-3 highly unsaturated fatty acid rich oil-in-water emulsions. Food chemistry, 141, 3077-3084. http://dx.doi.org/10.1016/j.foodchem.2013.05.143.

[30] Katalinic, V., Milos, M., Kulisic, T., \& Jukic, M. (2006). Screening of 70 medicinal plant extracts for antioxidant capacity and total phenols. Food chemistry, 94, 550-557. http://dx.doi.org/10.1016/j.foodchem.2004.12.004.

[31] Kim, D.-O., \& Lee, C. Y. (2004). Comprehensive study on vitamin $\mathrm{C}$ equivalent antioxidant capacity (VCEAC) of various polyphenol- ics in scavenging a free radical and its structural relationship. Critical reviews in food science and nutrition, 44, 253-273. http://dx.doi.org/10.1080/10408690490464960.

[32] Kim, J. W., Lee, J. H., Hwang, B. Y., Mun, S. H., Ko, N. Y., Kim, D. K., Kim, B., Kim, H. S., Kim, Y. M., \& Choi, W. S. (2009). Morin inhibits Fyn kinase in mast cells and IgE-mediated type I hypersensitivity response in vivo. Biochemical pharmacology, 77, 1506-1512. http://dx.doi.org/10.1016/j.bcp.2009.01.019.

[33] Kok, L., Wong, Y., Wu, T., Chan, H., Kwok, T., \& Fung, K. (2000) Morin hydrate: a potential antioxidant in minimizing the freeradicals-mediated damage to cardiovascular cells by anti-tumor drugs. Life sciences, 67, 91-99. http://dx.doi.org/10.1016/S00243205(00)00605-6.

[34] Kolodziej, H., Kayser, O., Latté, K. P., \& Ferreira, D. (1999). Evaluation of the antimicrobial potency of tannins and related compounds using the microdilution broth method. Planta medica, 65 444-446. http://dx.doi.org/10.1055/s-2006-960806.

[35] Kongkachuichai, R., Charoensiri, R., Yakoh, K., Kringkasemsee, A., \& Insung, P. (2015). Nutrients value and antioxidant content of indigenous vegetables from Southern Thailand. Food chemistry, 173, 838-846. http://dx.doi.org/10.1016/i.foodchem.2014.10.123.

[36] Li, Y., Jiang, B., Zhang, T., Mu, W., \& Liu, J. (2008). Antioxidant and free radical-scavenging activities of chickpea protein hydrolysate (CPH). Food chemistry, 106, 444-450. http://dx.doi.org/10.1016/j.foodchem.2007.04.067.

[37] Lopez-Cervantes, J., Sanchez-Machado, D. I., \& Rios-Vazquez, N. J. (2006). High-performance liquid chromatography method for the simultaneous quantification of retinol, alpha-tocopherol, and cholesterol in shrimp waste hydrolysate. J Chromatogr A, 1105, 135139. http://dx.doi.org/10.1016/j.chroma.2005.08.010.

[38] Lowry, O. H., Rosebrough, N. J., Farr, A. L., \& Randall, R. J. (1951). Protein measurement with the Folin phenol reagent. J biol Chem, 193, 265-275.

[39] Manach, C., Williamson, G., Morand, C., Scalbert, A., \& Remesy, C. (2005). Bioavailability and bioefficacy of polyphenols in humans. I. Review of 97 bioavailability studies. Am J Clin Nutr, 81, 230s-242s

[40] Martin, C., Butelli, E., Petroni, K., \& Tonelli, C. (2011). How can research on plants contribute to promoting human health? The Plant Cell, 23, 1685-1699. http://dx.doi.org/10.1105/tpc.111.083279.

[41] Morand, C., Manach, C., Crespy, V., \& Remesy, C. (2000). Respective bioavailability of quercetin aglycone and its glycosides in a rat model. Biofactors, 12, 169-174. http://dx.doi.org/10.1002/biof.5520120127.

[42] Okuda, K. (1992). Hepatocellular carcinoma: recent progress. Hepatology, 15, 948-963. http://dx.doi.org/10.1002/hep.1840150532.

[43] Okuda, T. (2005). Systematics and health effects of chemically distinct tannins in medicinal plants. Phytochemistry, 66, 2012-2031. http://dx.doi.org/10.1016/j.phytochem.2005.04.023.

[44] Orabi, S. A., \& Abdelhamid, M. T. (2014). Protective role of $\alpha$ tocopherol on two Vicia faba cultivars against seawater-induced lipid peroxidation by enhancing capacity of anti-oxidative system. Journal of the Saudi Society of Agricultural Sciences.

[45] Oumarou, B.-F. A., Tchuemdem, L. M., Djomeni, P. D. D., Bilanda, D. C., Tom, E. N. L., Ndzana, M. T. B., \& Théophile, D. (2013). Mineral constituents and toxicological profile of Jateorhiza macrantha (Menispermaceae) aqueous extract. Journal of ethnopharmacology, 149, 117-122. http://dx.doi.org/10.1016/j.jep.2013.05.054.

[46] Ozgen, M., Reese, R. N., Tulio, A. Z., Scheerens, J. C., \& Miller, A R. (2006). Modified 2, 2-azino-bis-3-ethylbenzothiazoline-6sulfonic acid (ABTS) method to measure antioxidant capacity of selected small fruits and comparison to ferric reducing antioxidant power (FRAP) and 2, 2'-diphenyl-1-picrylhydrazyl (DPPH) methods. J Agric Food Chem, 54, 1151-1157. http://dx.doi.org/10.1021/jf051960d.

[47] Ozturk, H., Kolak, U., \& Meric, C. (2011). Antioxidant, anticholinesterase and antibacterial activities of Jurinea consanguinea DC. Records of Natural Products, 5, 43-51.

[48] Palacios, C., \& Gonzalez, L. (2014). Is vitamin D deficiency a major global public health problem? The Journal of steroid biochemistry and molecular biology, 144, 138-145. http://dx.doi.org/10.1016/j.jsbmb.2013.11.003.

[49] Petti, S., \& Scully, C. (2009). Polyphenols, oral health and disease: A review. Journal of dentistry, 37, 413-423. http://dx.doi.org/10.1016/j.jdent.2009.02.003.

[50] Polat, R., Cakilcioglu, U., Kaltalioğlu, K., Ulusan, M. D., \& Türkmen, Z. (2015). An ethnobotanical study on medicinal plants in Espiye and its surrounding (Giresun-Turkey). Journal of ethnopharmacology, 163, 1-11. http://dx.doi.org/10.1016/j.jep.2015.01.008 
[51] [50] Qin, J., Li, Y., Cai, Z., Li, S., Zhu, J., Zhang, F., Liang, S., Zhang, W., Guan, Y., \& Shen, D. (2012). A metagenome-wide association study of gut microbiota in type 2 diabetes. Nature, 490, 55-60. http://dx.doi.org/10.1038/nature11450.

[52] Quimby, E. L. (2007). The use of herbal therapies in pediatric oncology patients: treating symptoms of cancer and side effects of standard therapies. Journal of Pediatric Oncology Nursing, 24, 35 40. http://dx.doi.org/10.1177/1043454206296027.

[53] Robards, K., Prenzler, P. D., Tucker, G., Swatsitang, P., \& Glover, W. (1999). Phenolic compounds and their role in oxidative processes in fruits. Food chemistry, 66, 401-436. http://dx.doi.org/10.1016/S0308-8146(99)00093-X.

[54] Sánchez-Moreno, C., A. Larrauri, J., \& Saura-Calixto, F. (1999). Free radical scavenging capacity and inhibition of lipid oxidation of wines, grape juices and related polyphenolic constituents. Food Research International, 32, 407-412. http://dx.doi.org/10.1016/S09639969(99)00097-6.

[55] Shan, B., Cai, Y.-Z., Brooks, J. D., \& Corke, H. (2007). The in vitro antibacterial activity of dietary spice and medicinal herb extracts. International Journal of food microbiology, 117, 112-119. http://dx.doi.org/10.1016/i.ijfoodmicro.2007.03.003.

[56] Sinare, H., \& Gordon, L. J. (2015). Ecosystem services from woody vegetation on agricultural lands in Sudano-Sahelian West Africa. Agriculture, Ecosystems \& Environment, 200, 186-199. http://dx.doi.org/10.1016/j.agee.2014.11.009.

[57] Singh, M. K., Gangwar, M., Kumar, D., Tilak, R., Nath, G., \& Agarwal, A. (2014). In vitro antimicrobial activity of ophenylenediamine-tert-butyl-N-1, 2, 3-triazole carbamate analogs. Medicinal Chemistry Research, 23, 4962-4976. http://dx.doi.org/10.1007/s00044-014-1063-4.

[58] Singleton, V., \& Rossi, J. A. (1965). Colorimetry of total phenolics with phosphomolybdic-phosphotungstic acid reagents. American journal of Enology and Viticulture, 16, 144-158.

[59] Smith, Y. A. (2009). Determination of chemical composition of Senna-siamea (Cassia leaves). Pakistan Journal of Nutrition, 8, 119 121. http://dx.doi.org/10.3923/pjn.2009.119.121.

[60] Velioglu, Y., Mazza, G., Gao, L., \& Oomah, B. (1998). Antioxidant activity and total phenolics in selected fruits, vegetables, and grain products. J Agric Food Chem, 46, 4113-4117. http://dx.doi.org/10.1021/jf9801973.

[61] Wang, Y., Ramsey, R., \& Hamilton, A. F. d. C. (2011). The contro of mimicry by eye contact is mediated by medial prefrontal cortex. The Journal of neuroscience, 31, 12001-12010. http://dx.doi.org/10.1523/JNEUROSCI.0845-11.2011.

[62] Wedick, N. M., Pan, A., Cassidy, A., Rimm, E. B., Sampson, L., Rosner, B., Willett, W., Hu, F. B., Sun, Q., \& van Dam, R. M. (2012). Dietary flavonoid intakes and risk of type 2 diabetes in US men and women. The American journal of clinical nutrition, ajen. 028894. http://dx.doi.org/10.3945/ajen.111.028894.

[63] Wong, C.-C., Li, H.-B., Cheng, K.-W., \& Chen, F. (2006). A systematic survey of antioxidant activity of 30 Chinese medicinal plants using the ferric reducing antioxidant power assay. Food chemistry, 97 ,

$705-711$. http://dx.doi.org/10.1016/j.foodchem.2005.05.049.

[64] Xiao, Z.-P., Peng, Z.-Y., Peng, M.-J., Yan, W.-B., Ouyang, Y.-Z. \& Zhu, H.-L. (2011). Flavonoids health benefits and their molecular mechanism. Mini reviews in medicinal chemistry, 11, 169-177. http://dx.doi.org/10.2174/138955711794519546.

[65] Yang, S.-F., Yang, W.-E., Kuo, W.-H., Chang, H.-R., Chu, S.-C., \& Hsieh, Y.-S. (2008). Antimetastatic potentials of flavones on ora cancer cell via an inhibition of matrix-degrading proteases. $\mathrm{Ar}$ chives of oral biology, 53, 287-294. http://dx.doi.org/10.1016/i.archoralbio.2007.09.001.

[66] Yen, G.-C., \& Wu, J.-Y. (1999). Antioxidant and radical scaveng ing properties of extracts from Ganoderma tsugae. Food chemistry, 65, 375-379. http://dx.doi.org/10.1016/S0308-8146(98)00239-8.

[67] Yisa, J., \& Jimoh, T. (2010). Analytical studies on water quality index of river Landzu. American Journal of Applied Sciences, 7 , 453. http://dx.doi.org/10.3844/ajassp.2010.453.458.

[68] Yoshida, N., Springel, V., White, S. D., \& Tormen, G. (2000) Weakly self-interacting dark matter and the structure of dark halos. The Astrophysical Journal Letters, 544, L87. http://dx.doi.org/10.1086/317306.

[69] Zheng, X.-k., Zhang, L., Wang, W.-w., Wu, Y.-y., Zhang, Q.-b., \& Feng, W.-s. (2011). Anti-diabetic activity and potential mechanism of total flavonoids of Selaginella tamariscina (Beauv.) Spring in rats induced by high fat diet and low dose STZ. Journal of ethnopharmacology, 137 , 662-668.
[70] Zhishen, J., Mengcheng, T., \& Jianming, W. (1999). The determination of flavonoid contents in mulberry and their scavenging effects on superoxide radicals. Food chemistry, 64, 555-559. http://dx.doi.org/10.1016/S0308-8146(98)00102-2.

[71] Zu, Y., Li, C., Fu, Y., \& Zhao, C. (2006). Simultaneous determination of catechin, rutin, quercetin kaempferol and isorhamnetin in the extract of sea buckthorn (Hippophae rhamnoides L.) leaves by RP-HPLC with DAD. Journal of pharmaceutical and biomedical analysis, 41, 714-719. http://dx.doi.org/10.1016/j.jpba.2005.04.052.

[72] Žugić, A., Đorđević, S., Arsić, I., Marković, G., Živković, J., Jovanović, S., \& Tadić, V. (2014). Antioxidant activity and phenolic compounds in 10 selected herbs from Vrujci Spa, Serbia. Industrial Crops and Products, 52, 519-527. http://dx.doi.org/10.1016/j.indcrop.2013.11.027. 